\title{
A Study of Experience Credit for Professional Engineering Licensure
}

\section{July 2003}

\author{
Prepared by \\ Michaela Martin, P.E. \\ Oak Ridge National Laboratory \\ Kurt Stafford \\ University of Tennessee, Knoxville \\ Oak Ridge National Laboratory
}




\title{
DOCUMENT AVAILABILITY
}

Reports produced after January 1, 1996, are generally available free via the U.S. Department of Energy (DOE) Information Bridge:

Web site: http://www.osti.gov/bridge

Reports produced before January 1, 1996, may be purchased by members of the public from the following source:

\author{
National Technical Information Service \\ 5285 Port Royal Road \\ Springfield, VA 22161 \\ Telephone: 703-605-6000 (1-800-553-6847) \\ TDD: $703-487-4639$ \\ Fax: 703-605-6900 \\ E-mail: info@ntis.fedworld.gov \\ Web site: http://www.ntis.gov/support/ordernowabout.htm
}

Reports are available to DOE employees, DOE contractors, Energy Technology Data Exchange (ETDE) representatives, and International Nuclear Information System (INIS) representatives from the following source:

Office of Scientific and Technical Information

P.O. Box 62

Oak Ridge, TN 37831

Telephone: 865-576-8401

Fax: 865-576-5728

E-mail: reports@adonis.osti.gov

Web site: http://www.osti.gov/contact.html

This report was prepared as an account of work sponsored by an agency of the United States Government. Neither the United States government nor any agency thereof, nor any of their employees, makes any warranty, express or implied, or assumes any legal liability or responsibility for the accuracy, completeness, or usefulness of any information, apparatus, product, or process disclosed, or represents that its use would not infringe privately owned rights. Reference herein to any specific commercial product, process, or service by trade name, trademark, manufacturer, or otherwise, does not necessarily constitute or imply its endorsement, recommendation, or favoring by the United States Government or any agency thereof. The views and opinions of authors expressed herein do not necessarily state or reflect those of the United States Government or any agency thereof. 


\section{A Study of Experience Credit for Professional Engineering Licensure}

Michaela Martin, P.E.

Kurt Stafford

July 2003

Prepared by

OAK RIDGE NATIONAL LABORATORY

P.O. Box 2008

Oak Ridge, Tennessee 37831-6285

managed by

UT-Battelle, LLC

for the

U.S. DEPARTMENT OF ENERGY

under contract DE-AC05-00OR22725 



\section{Contents}

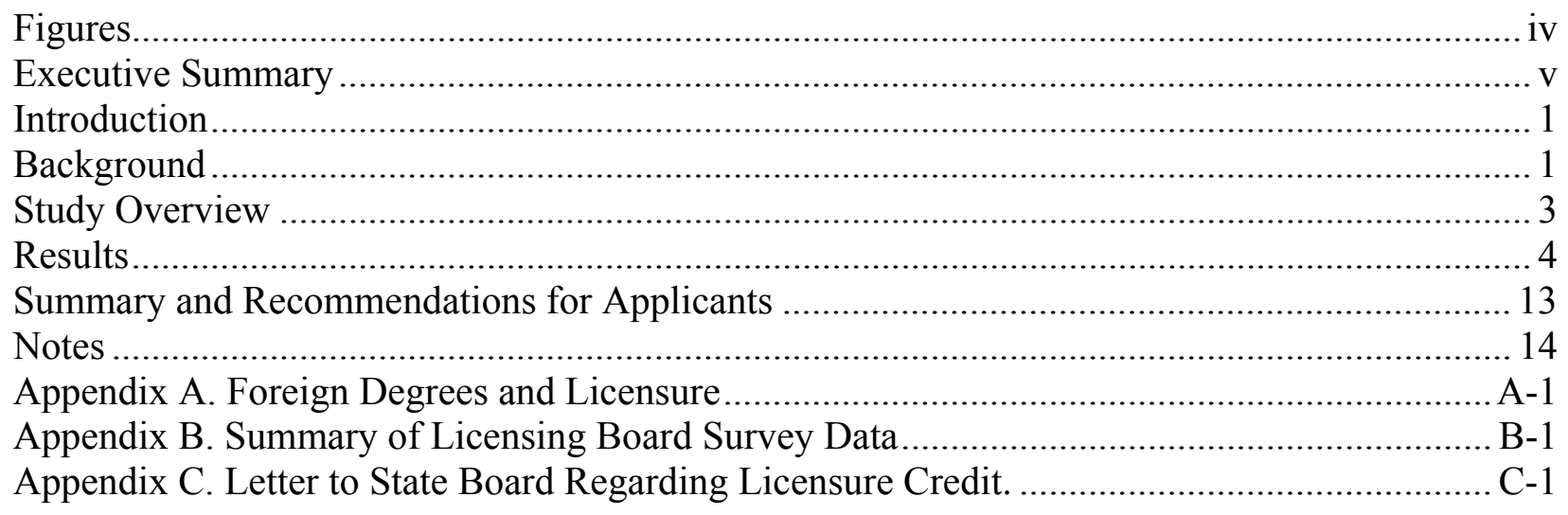




\section{Figures}

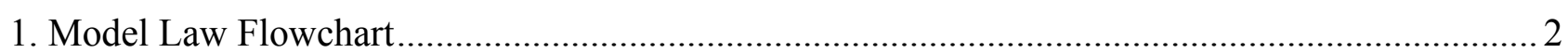

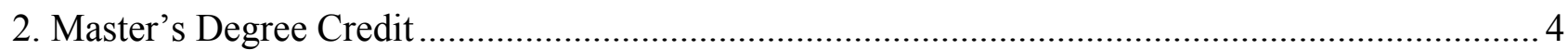

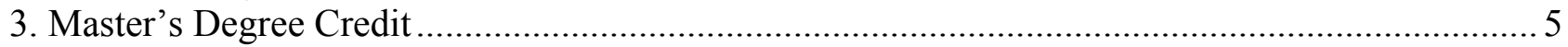

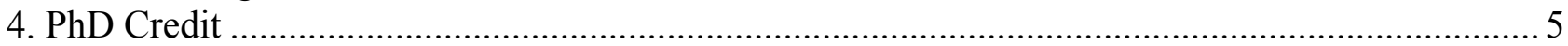

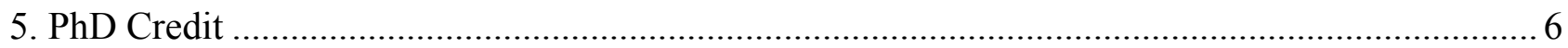

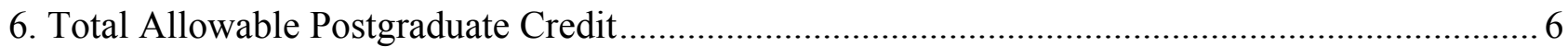

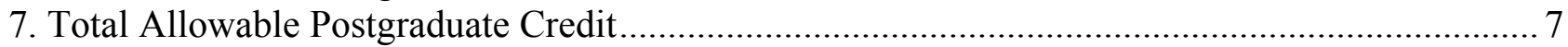

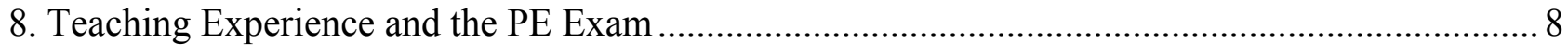

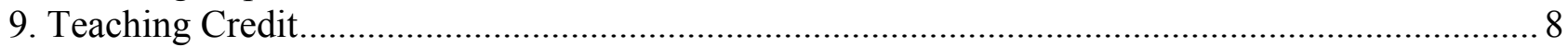

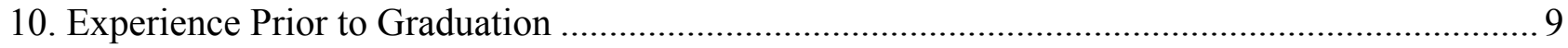

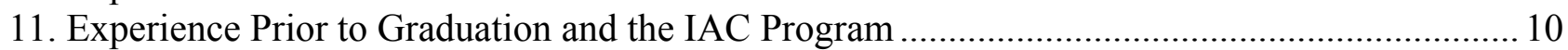

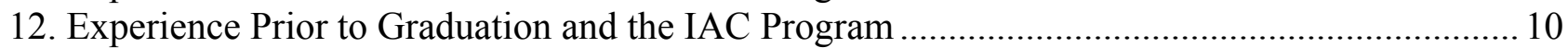

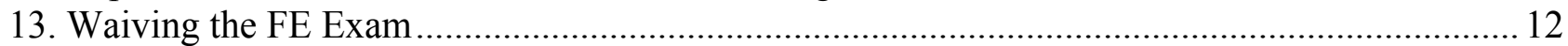






\section{Executive Summary}

Oak Ridge National Laboratory performed a study of experience credit for professional engineering licensure for the Department of Energy's Industrial Assessment Center (IAC) Program. One of the study's goals was to determine how state licensure boards grant experience credit for engineering licensure, particularly in regards to IAC experience and experience prior to graduation. Another goal involved passing IAC information to state licensure boards to allow the boards to become familiar with the program and determine if they would grant credit to IAC graduates.

The National Council of Examiners for Engineers and Surveyors (NCEES) has adopted a document, the "Model Law." This document empowers states to create state engineering boards and oversee engineering licensure. The board can also interpret and adopt rules and regulations. The Model Law also gives a general "process" for engineering licensure, the "Model Law Engineer." The Model Law Engineer requires that an applicant for professional licensure, or professional engineering (PE) licensure, obtain a combination of formal education and professional experience and successfully complete the fundamentals of engineering (FE) and PE exams.

The Model Law states that a PE applicant must obtain four years of "acceptable" engineering experience after graduation to be allowed to sit for the PE exam. Although the Model Law defines "acceptable experience," it is somewhat open to interpretation, and state boards decide whether applicants have accumulated the necessary amount of experience. The Model Law also allows applicants one year of credit for postgraduate degrees as well as experience credit for teaching courses in engineering.

The Model Law grants states the power to adopt and amend the bylaws and rules of the Model Law licensure process. It allows state boards the freedom to modify the experience requirements for professional licensure. This power has created variety in experience requirements, and licensure requirements can differ from state to state.

Before this study began, six questions were developed to help document how state boards grant experience credit. Many of the questions were formulated to determine how states deal with teaching experience, postgraduate credit, experience prior to graduation, PE and FE waivers, and the licensure process in general.

Data were collected from engineering licensure boards for each of the fifty states and the District of Columbia. Telephone interviews were the primary method of data collection, while email correspondence was also used to a lesser degree. Prior to contacting each board, the researchers attempted to review each state's licensure web site.

Based on the data collected, several trends and patterns were identified. For example, there is a general trend away from offering credit for experience prior to graduation. The issue becomes a problem when a PE from one state attempts to gain a license in another state by comity or endorsement. Tennessee and Kansas have recently stopped offering this credit and Mississippi cautions applicants that it could be difficult to obtain licensure in other states.

Because PE licensure is very important for engineers, IAC students need to keep track of their professional experience and ensure that when they graduate, their work is considered "acceptable" 
to the state board. Students should also take the FE exam as soon possible after graduation. The longer they wait, the less likely they are to be successful on the exam.

IAC Directors and Assistant Directors may have the experience needed to be eligible to take the PE exam. Virtually all states allow teaching experience to count towards the PE exam. Some states will also allow PhDs to waive the FE exam. Because academic professionals write both the FE and PE exams, professors and other academic professionals should score well on them.

Of the 25 state boards that accept work experience prior to graduation, only 12 could currently accept IAC experience. If the IAC program wants its students to receive credit in these states, it must tailor the program to more closely resemble cooperative engineering programs. These states list requirements that only students with this type of experience can fulfill.

The licensure process is currently in a state of reevaluation. The NCEES has a panel reviewing Model Law requirements. The American Society of Civil Engineers (ASCE) has forwarded a proposal calling for a master's degree or equivalent for professional licensure. This proposal would raise the educational requirements for PEs. The National Society of Professional Engineers (NSPE) is also involved in the current licensure debate and has proposed several changes to Model Law requirements. 



\section{Introduction}

The following study was conducted by Oak Ridge National Laboratory for the Department of Energy's Industrial Assessment Center (IAC) Program. The goal was to develop a clear idea of how each state grants experience credit towards professional licensure with regard to IAC experience before graduation and the teaching experience of IAC Directors and Assistant Directors. Information was documented on the types of experience that state boards commonly recognize as "acceptable." This paper will summarize these results and draw conclusions based on the data collected from discussions with the state boards and a review of material located on states' licensure web sites.

\section{Background}

To protect public safety, state laws require that engineers obtain a professional engineering (PE) license before they can offer public services or sign and seal plans for public use. These laws govern the conduct and ethics of PEs and help to safeguard the public against misrepresentation and malpractice. A PE license is earned through a series of steps that involve a combination of formal education, examination, and professional experience.

A document called the Model Law outlines the process of obtaining PE licensure. The document was approved in 1932 by the National Council of State Boards of Engineering Examiners (CSBEE), predecessor to the current National Council of Examiners for Engineers and Surveyors (NCEES). The NCEES is a national nonprofit organization composed of engineering and land surveying licensing boards, representing all U.S. states and territories. The agency manages the writing and scoring of standardized tests for engineers and land surveyors. ${ }^{1}$

The NCEES Model Law defines the process of PE licensure in its description of the "Model Law Engineer." This term refers to a person who: “(A) Is the graduate of an engineering program accredited by the Engineering Accreditation Commission of the Accreditation Board for Engineering and Technology (EAC/ABET); (B) Has passed an eight-hour NCEES Fundamentals of Engineering (FE) exam and an eight-hour NCEES Principles and Practice of Engineering (PE) exam using the NCEES cut score; (C) Has completed four years of acceptable engineering experience after confirmation of a bachelor of science degree in an engineering curriculum, which may include up to one year of experience for a graduate engineering degree; and (D) Has a record clear of disciplinary action". ${ }^{2}$ Figure 1 illustrates the process of licensure according to the NCEES Model Law. The Model Law establishes a general framework for engineering licensure programs. This framework is adopted and modified by the states to meet the individual needs of their constituencies.

As noted in the description of The Model Law Engineer, a formal engineering education is part of the licensure process. The document specifies that this education must be received at an EAC/ABET accredited institution. EAC/ABET is a federation of engineering and technical societies that provides quality assurance for engineering programs through a review process called accreditation. $^{3}$

The process for obtaining a PE license begins with successfully completing the FE exam. Some examinees are eligible to take this exam during their senior year of college; however, taking the 


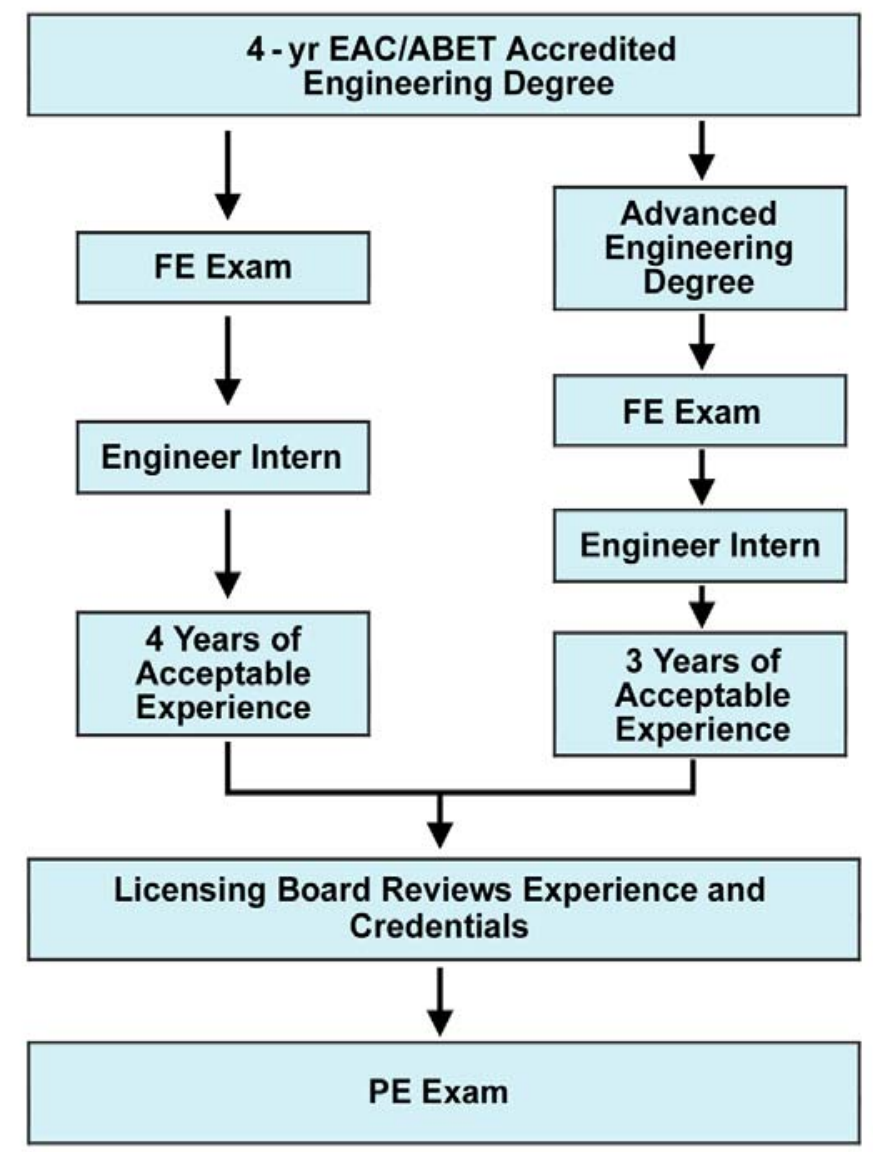

Fig. 1. Model Law Flowchart exam during college is not required. After successfully completing the FE exam, the applicant is then qualified for certification. States generally refer to this certification as engineer-in-training (EIT), but several use either engineer intern (EI) or intern engineer. ${ }^{4}$ Once the EIT achieves the designated amount of professional experience mandated by their particular state, they must pass the Principles and Practice (PE) exam to qualify for licensure.

Professional experience is important for engineers. The Model Law states that a PE applicant should have four years of experience after graduation and this experience should be of an "acceptable" nature. What is "acceptable" experience?

The Model Law describes it as "progressive" and "of a grade and character that indicates to the board that the applicant may be competent to practice engineering." It also defines the practice of engineering as "service or creative work" that "requires engineering education, training, and experience in the application of special knowledge of the mathematical, physical

and engineering sciences." "Section 12 of the Law defines the general requirements for licensure. It states that to be eligible for the PE examination, an applicant must supply five references, three of which should be from PEs with knowledge of the applicant's experience.

The Model Law allows for other types of experience credit. A graduate degree in engineering can be substituted for one year of experience. Teaching is also recognized as engineering experience. According to the Model Law, this type of experience must be gained in an approved engineering curriculum of four or more years. The experience must also be earned in the process of teaching advanced subjects and designing research projects. ${ }^{7}$

The Model Law provides each individual state the power to adopt their own set of rules and regulations. Many of these differ from the Model Law on the requirements for experience and education. Although each state uses the same standardized tests and scoring criteria for the PE exam, requirements for examinees can differ from state to state with respect to education and experience. $^{7}$

The Model Law allows states to set up a board to govern the process of licensure. Each state has created an independent engineering board that serves as a law-making and law-interpreting body. Fees for licensure and licensure renewal generally fund these boards. Section 8 of The Model Law elaborates on the power awarded these boards. Subsection A reads, "The board shall have the power to adopt and amend bylaws and rules of procedure not inconsistent with the constitution and laws of this jurisdiction or this Act." ${ }^{8}$ Subsection H gives the board other rights: "The board shall have the 
power and authority to waive requirements of this law pertaining to surveying and engineering licensure provided consideration is given to safeguarding life, health, and property, and promoting the public welfare." Both of these subsections give state boards considerable freedom and power. While boards possess this power, engineers and applicants are allowed to present issues, either formally or informally, to the board for consideration. The boards generally consist of appointed persons and are composed of professional surveyors or land surveyors, PEs, and public members appointed by the Governor. ${ }^{7}$

State boards also review PE applications and decide whether to allow applicants to sit for the exam. These decisions are based on an evaluation of an applicant's education and experience. Several boards use an outside contractor to evaluate applications. Applicants educated abroad may have problems converting their educational experience into the proper format for the PE and FE applications. See Appendix A for further information on foreign degrees and licensure.

\section{Study Overview}

Prior to beginning this study, six questions were developed. These questions were created using experience criteria gathered from The Model Law. They were used to document how each state has modified the Model Law and how each grants experience credit for the PE examination. The six questions were as follows:

1. In addition to graduation from a four-year EAC/ABET-accredited curriculum, what are the general requirements to be allowed to sit for the PE exam?

2. Does a master's degree from an EAC/ABET-accredited curriculum count as experience toward licensure?

3. Does a PhD from an EAC/ABET-accredited curriculum count as experience toward licensure?

4. Is teaching class in a four-year EAC/ABET-accredited curriculum considered acceptable as experience toward licensure?

5. Is any credit given to experience gained prior to graduation? If so, what are the requirements and maximum amount of obtainable credit?

6. Can either the PE or FE exams be waived based on experience or education?

Data were collected from engineering boards for each of the 50 states and the District of Columbia. Telephone interviews were the primary method of data collection for this study. E-mail correspondence was also used to a lesser degree for follow-up questions and other inquiries. Prior to contacting each board, an attempt was made to research each state's licensure web site. Many boards post their rules and regulations on public websites. These sites are accessible from www.ncees.org. As of December 2002, 49 of the 51 surveyed licensing boards had web sites accessible through the NCEES site. After researching the board's rules and regulations, the state or district was contacted and additional data were collected. The table in Appendix B summarizes the collected data. 


\section{Results}

\section{Question 1: After graduation from a four-year EAC/ABET-accredited curriculum, what are the general requirements to be allowed to sit for the PE exam?}

In some states, it is possible to be admitted to the PE or FE examination with less that a fouryear ABET-accredited engineering degree. These applicants possess non-ABET accredited engineering degrees, engineering technology degrees, related degrees, or no educational background. Educational experience is made up for by work experience. States have devised a system of "tracks" to deal with applicants from differing educational backgrounds. For example, Idaho requires that graduates from non-ABET-accredited engineering programs possess 5 years of experience, while a graduate of an engineering technology program must have 6 years of experience to sit for the PE exam.

Of the 51 engineering boards surveyed, only 2 differ from the general requirements set forth by the Model Law. These requirements consist of obtaining a four-year or better ABET-accredited engineering degree, passing the FE exam, and gaining four years of "acceptable" experience. The state of California requires two years' experience instead of four. Hawaii does not require that applicants pass the FE exam, although it is encouraged.

\section{Question 2: Does a master's degree from an EAC/ABET-accredited curriculum count as experience toward licensure?}

The Model Law states that a graduate degree in engineering may be used for one year of experience toward licensure. In accordance, the vast majority of engineering boards will grant one year of qualifying experience for a master's degree (See Figs. 2 and 3). Of the 47 boards that do allow 1 year of credit for the master's degree, 15 have adopted regulations allowing for a maximum of 1 year of credit for postgraduate degrees. It is assumed that this credit will be used for a master's degree, but the year can be used for either the master's or PhD degree. Notable exceptions include California, Nevada, Pennsylvania, and Virginia. California will allow six months credit for the successful completion of a master's degree. Neither Nevada nor Pennsylvania currently allows for this type of credit. In Virginia, it is sometimes possible to get credit, but there are no set time designations, and the decision rests entirely with the state board.

It should also be noted

Figure 2. Master's Degree Credit that it takes most graduate students approximately two years to receive their master's degree, while most states offer only one year of credit for this advanced degree. This means that it would actually take less time to become eligible for the $\mathrm{PE}$ exam if a student declines to pursue a master's degree.

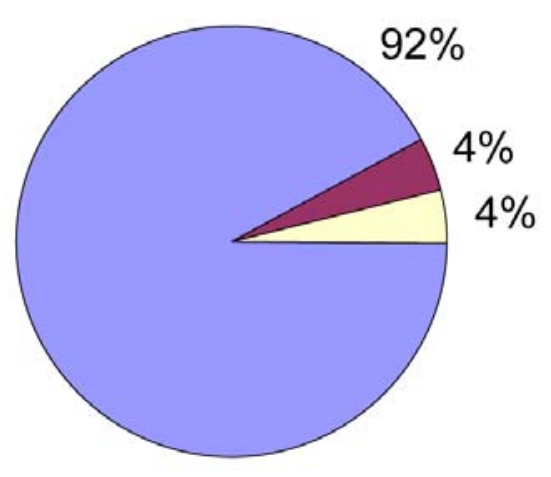

Allow 1 year for master's

Allow 0-1 year for master's

No credit for master's 


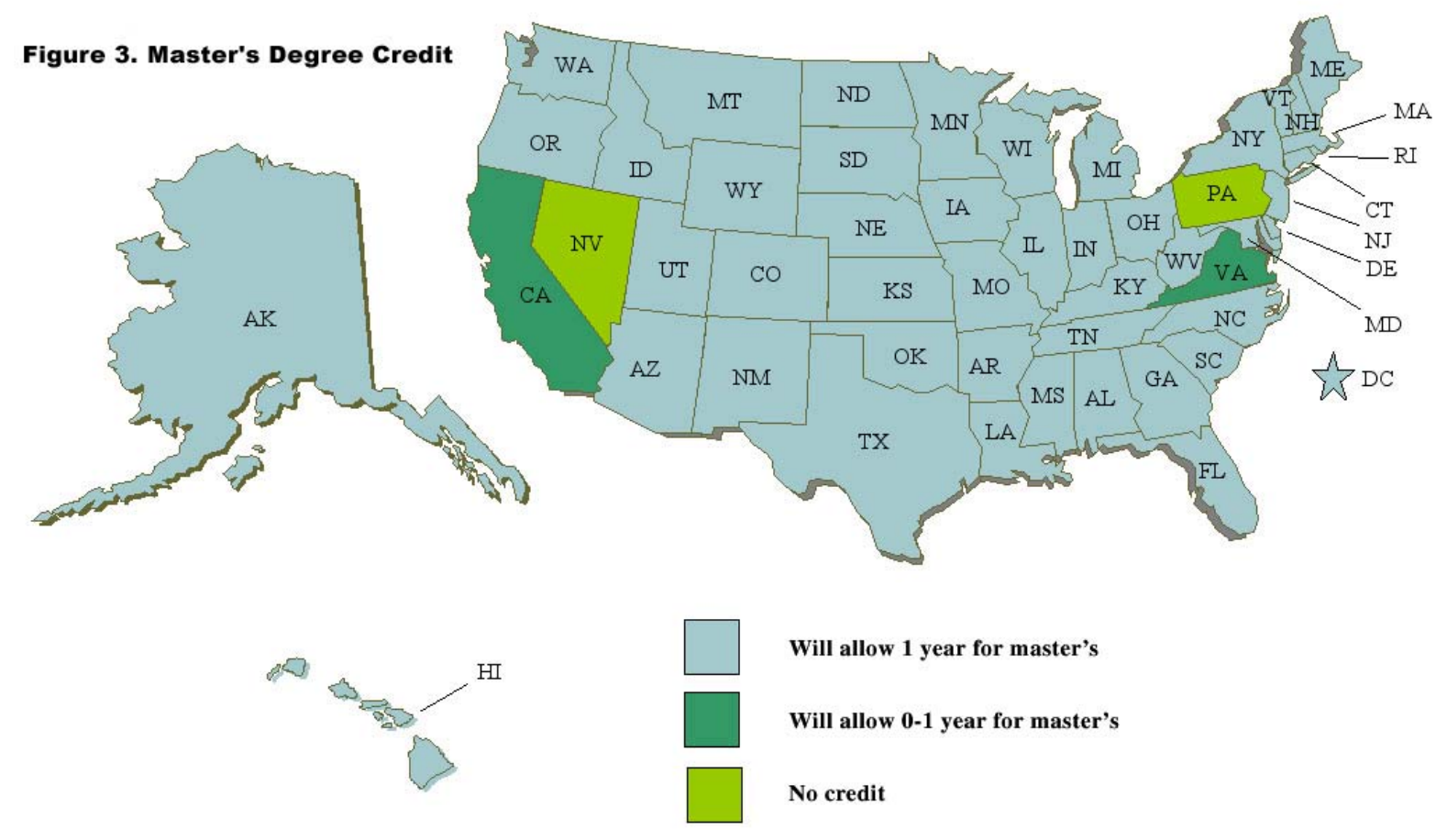

\section{Question 3: Does a PhD from an EAC/ABET-accredited curriculum count as experience toward licensure?}

As noted under Question 2, some state boards have adopted laws that allow for a maximum of one year's credit for successfully completing postgraduate study, while other states simply allow one year for completing a $\mathrm{PhD}$ degree. Each state that will allow a year for the $\mathrm{PhD}$ degree also allows one year for a master's degree. Fourteen of the surveyed boards did not grant credit for the $\mathrm{PhD}$ degree. Idaho is included in this group, but the board is currently reviewing that policy. Figures 4 and 5 detail how $\mathrm{PhD}$ credit is handled and how each state treats the issue.

Mississippi and California both grant credit for the degree, but not the typical year of credit. The state of Mississippi will allow two years for successfully completing a $\mathrm{PhD}$ while also allowing a

Figure 4. PhD Credit

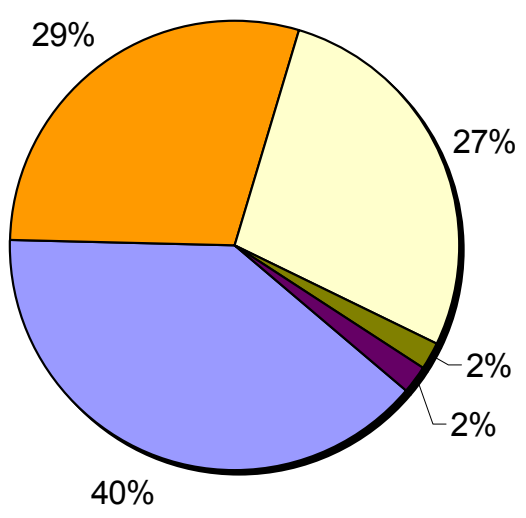

$\square 1$ year for $\mathrm{PhD}$

1 year maximum for postgraduate degrees

$\square$ No credit for $\mathrm{PhD}$

6 months for $\mathrm{PhD}$

2 years for $\mathrm{PhD}$ year for a master's degree. This would allow an applicant a total of three years of credit in Mississippi. Louisiana will allow two years for the $\mathrm{PhD}$ if the applicant has not already claimed one year for a master's in engineering. California will grant 6 months of credit. Note that California is quite similar to states that offer two years of credit for postgraduate degrees. The two sixmonth experience credits offered are proportional because California applicants need only two years' experience to sit for the PE exam. 


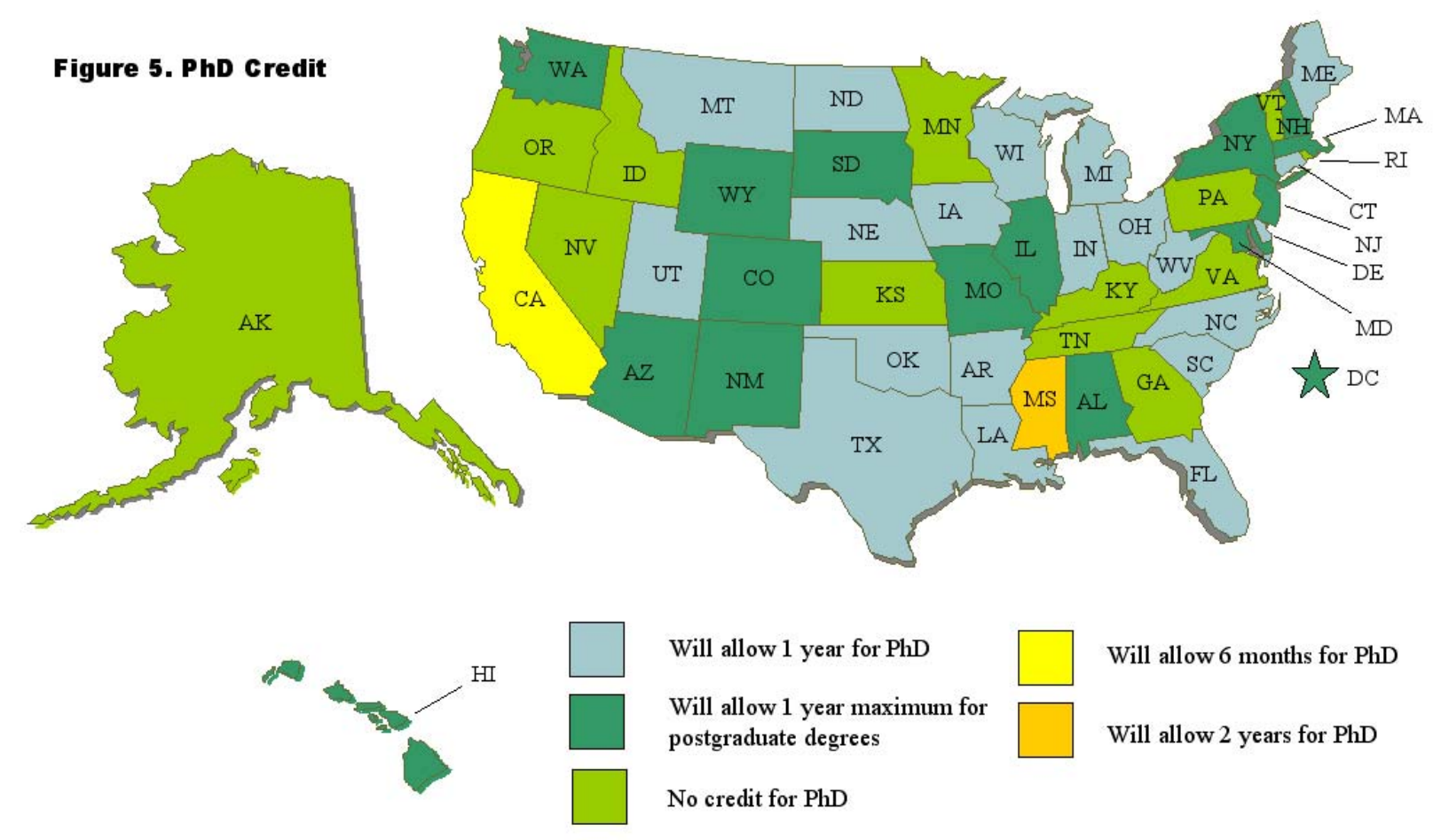

We have seen that postgraduate experience credit varies from state to state. State boards tend to deal with postgraduate credit in one of two ways. Some have adopted laws and regulations that treat master's and $\mathrm{PhD}$ degrees separately, while others allow a maximum of one year that can be applied to either. Figure 6 is an attempt to describe this variation by taking into account the total amount of credit offered by each state. Credit ranges from no time to 3 years' credit for a combination of master's and $\mathrm{PhD}$ degrees. Figure 7 outlines how much postgraduate credit each state gives.

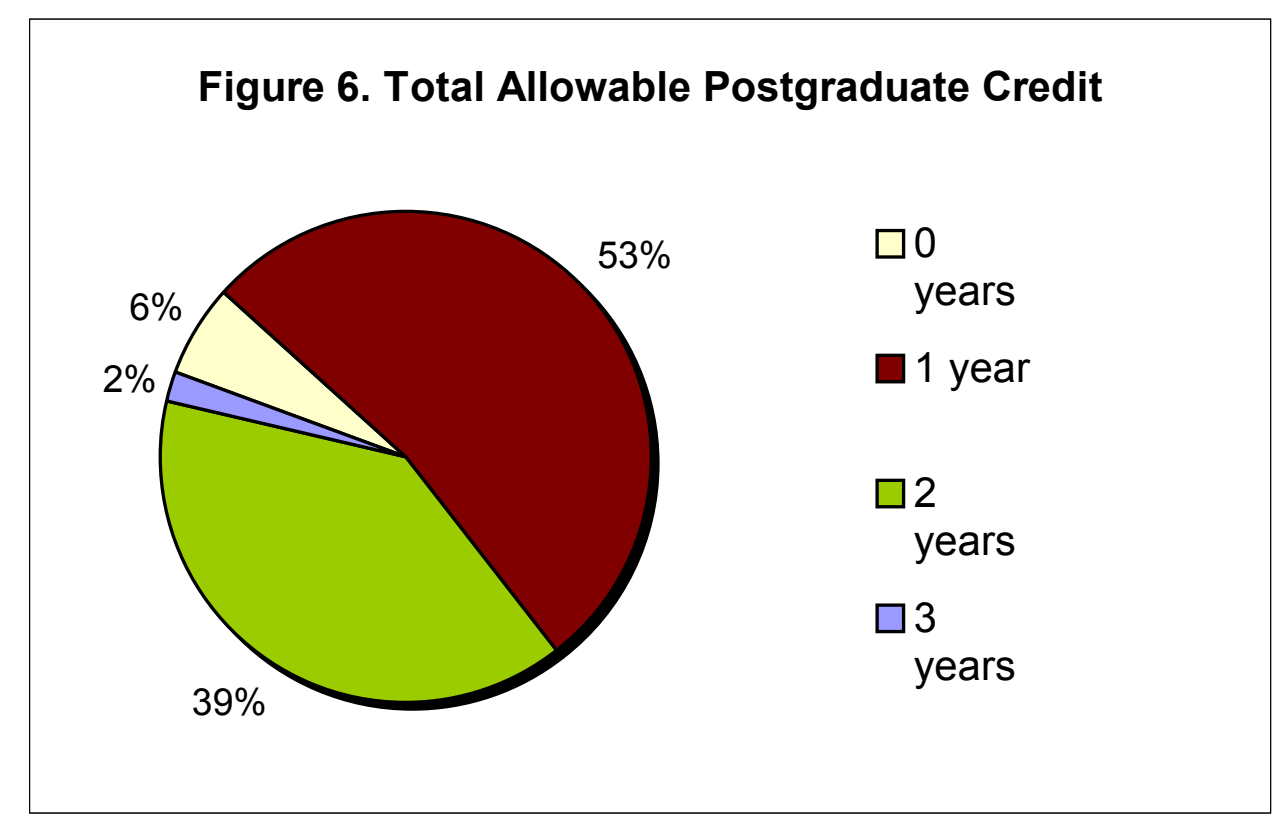




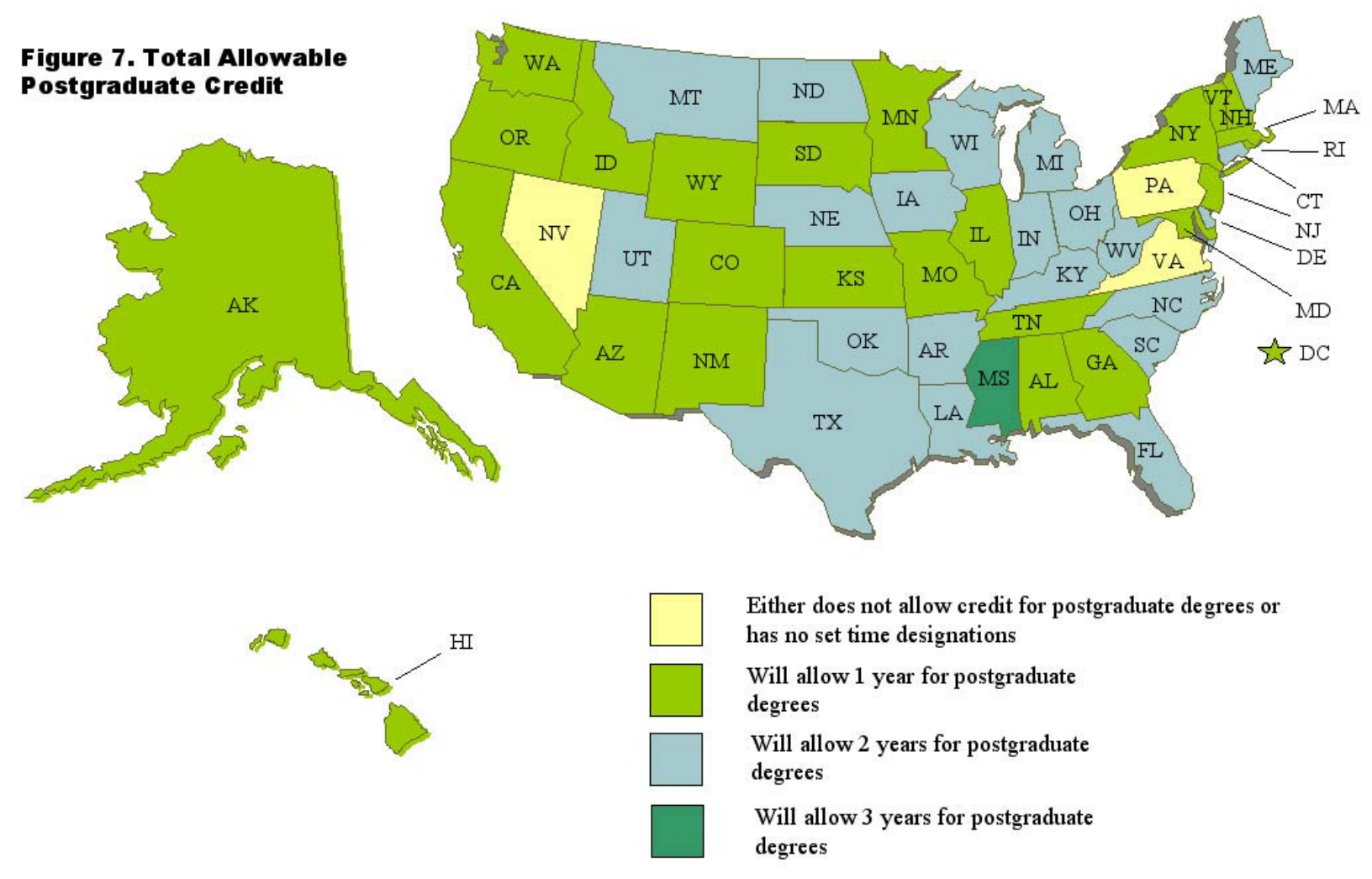

\section{Question 4: Is teaching classes in a four-year EAC/ABET accredited curriculum acceptable as experience toward licensure?}

The Model Law states that the practice of engineering includes the teaching of advanced engineering subjects. ${ }^{7}$ This enables state boards to grant engineering professors experience credit for time spent teaching.

Except for New Jersey, virtually all states surveyed allow experience credit for teachers. Many states have stipulations for this type of experience and evaluate each applicant on a case-by-case basis. For example, some states require that the experience be under the supervision of a registered PE. Other states specify that the courses taught be upper-level design classes. A few states require that teaching be concurrent with both consulting and research, and still others require that the experience be gained at a position equal to or above the associate professor level.

Four states do not allow teaching to comprise all of an applicant's engineering experienceArizona, North Dakota, Washington, and North Carolina expect professors to gain additional experience outside the teaching field. For example, Arizona allows a PE applicant one year for successfully completing a $\mathrm{PhD} /$ master's combination. An additional year is granted for teaching in an approved engineering curriculum. In this case, the applicant would still need to obtain two additional years of experience to be eligible to sit for the PE exam. Figures 8 and 9 show how state boards treat teaching experience. 


\section{Figure 8. Teaching Experience and the PE Exam}

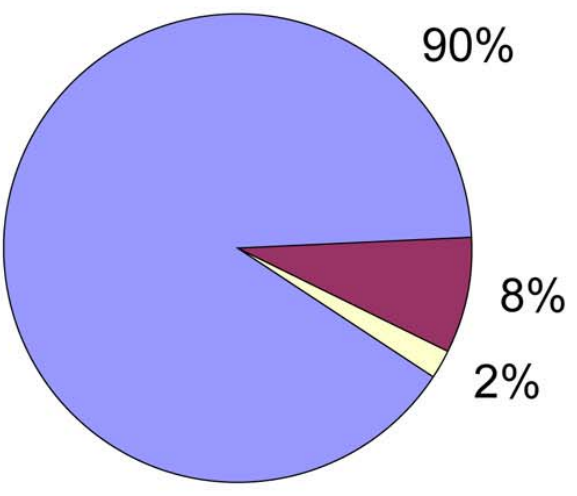

Applicant can fulfill experience requirements for PE exam based solely on teaching experience

Allow teaching credit, but additional experience is required to fulfill experience requirements for $\mathrm{PE}$ exam

No credit for teaching

Figure 9. Teaching Credit
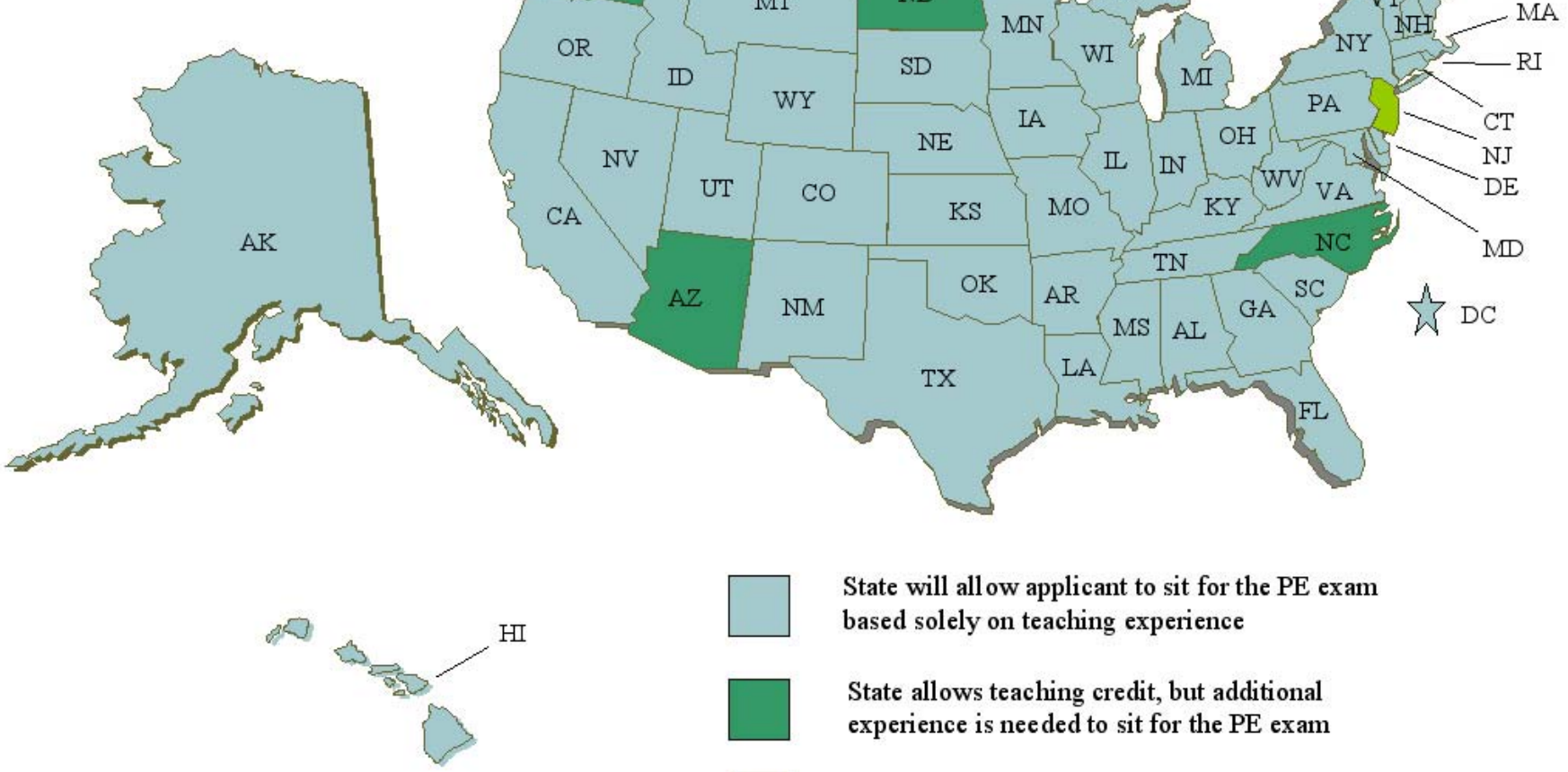

State will all ow applicant to sit for the PE exam based solely on teaching experience

State allows teaching credit, but additional experience is needed to sit for the $\mathrm{PE}$ exam

State does not allow te aching credit 


\section{Question 5: Is any credit given to experience gained prior to graduation? If so, what are the requirements and maximum amount of obtainable credit?}

State boards are almost evenly split on this question. Of the 51 boards surveyed, 25 allow experience credit prior to graduation. Of the boards that accept this experience, requirements and the amount of obtainable credit vary from state to state.

The IAC Program recently attempted to gain recognition by state boards for licensure credit. Upon initial contact with a state board, information concerning the IAC Program was presented to board officials. This information consisted of a formal letter detailing the IAC Program's interest in gaining licensure credit for students (Appendix B) and a brochure explaining the program (see Appendix C). In many states, the state board members reviewed the information, and several states issued formal decisions on IAC experience.

Of the 51 boards, 12, or 24 percent, would accept IAC experience. The state engineering boards of South Dakota, Utah, Washington, Arizona, Florida, Kentucky, Virginia, and New York indicated that they would accept IAC experience because they evaluate this type of experience case-by-case based on work descriptions and references. The maximum amount of credit ranged from 6 months to one year. The state board of Colorado noted that it could allow IAC experience to count if an applicant took longer than four years to acquire their undergraduate degree. The board would not allow education and work experience to overlap. Texas would accept IAC experience, but the applicant must have been at a junior or senior level in college. Ohio also required that the experience occur after the sophomore year and be subject to the same rules as experience gained after graduation. New Hampshire would recognize IAC experience as long as the applicant was working under PE guidance. Figure 10 shows the findings on experience prior to graduation, while Figure 11 concerns this type of experience and the IAC program. Figure 12

Figure 10. Experience Prior to Graduation

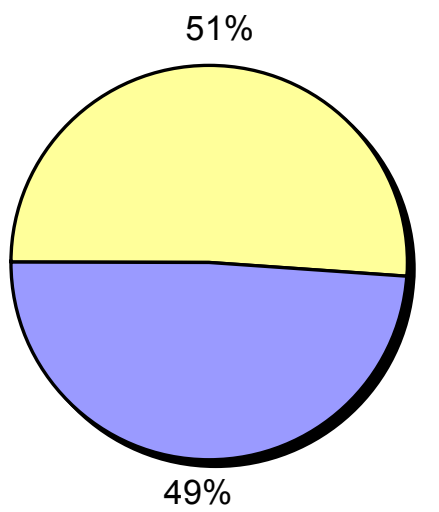

$\square$ Do not accept experience prior to graduation

Do accept experience prior to graduation

shows how each state handles IAC experience and experience prior to graduation. 
Figure 11. Experience Prior to Graduation and the IAC Program

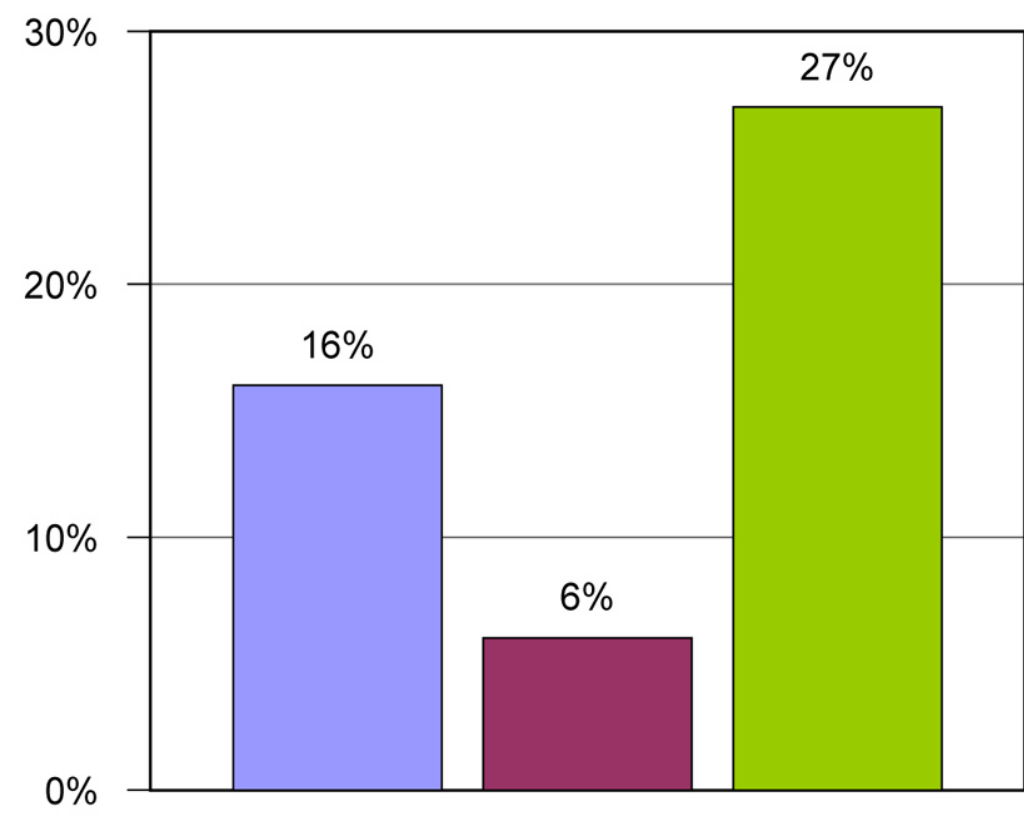

Will accept IAC experience

Will accept IAC experience subject to certain licensure regulations

Will accept experience prior to graduation but will not accept IAC experience

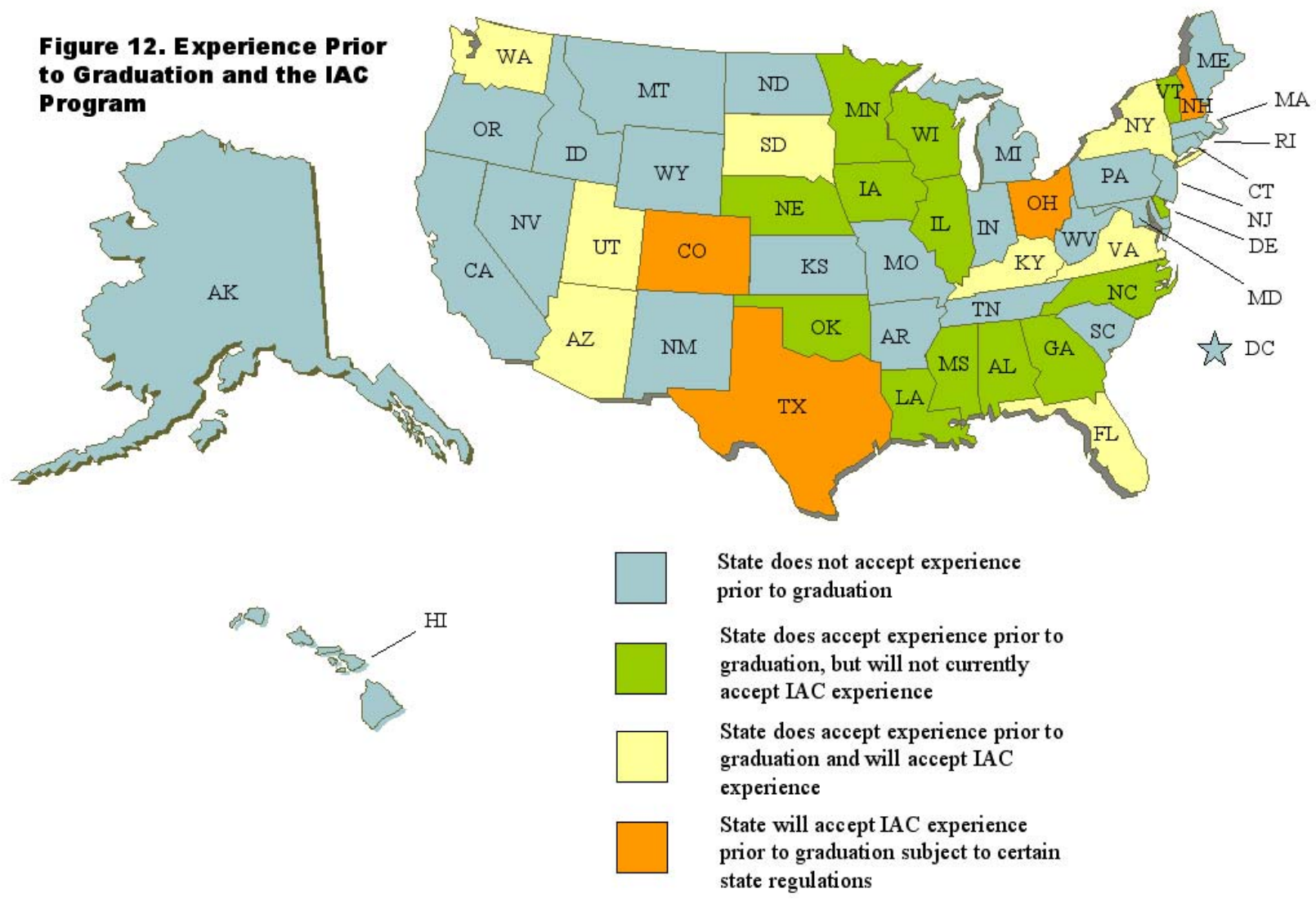


Many of the boards that do accept this type of experience have based their requirements on formal cooperative engineering programs. These programs utilize full-time work periods where students usually alternate semesters or quarters between work and school. Typically, these programs place students under the supervision of PEs. Because work periods last entire semesters or quarters, the work term is usually noted on the students' transcripts (e.g., "co-op in field"). Fourteen of the twenty-five state boards that do accept this experience specifically identify co-op experience in their requirements.

The three main requirements listed were that experience must be (1) under PE supervision, (2) recorded on transcripts, and (3) full-time. Professional engineers sometimes need to work in states other than the one in which they were originally licensed. In this situation, they can apply to other state boards to receive licensure by comity or endorsement. Comity is a process in which a state board will recognize an applicant's out-of-state PE license and grant the applicant an in-state license to practice engineering without forcing them to reapply and take the PE exam. ${ }^{7}$

The Model Law specifies that applicants must obtain four years of experience after the confirmation of the bachelor's degree. States who do not accept experience prior to graduation will not recognize the experience of PEs from states that do. Engineers who use this time to fulfill experience requirements have had problems obtaining PE licensure in states that do not accept it. These states have declined comity applications and in some cases have asked the applicants to retake the PE exam. The state of Mississippi has posted a cautionary note on its licensure website. It reads, "Applicants who complete an approved co-op program may (your choice) be given six months of "experience" credit, but be aware that other states may not recognize a PE exam taken before the full four years of experience was accrued after graduation". ${ }^{10}$ Tennessee, which originally did give this type of credit, has not done so in the past three years for similar reasons. Kansas stopped accepting this experience as of November 1, 2002.

\section{Question 6: Can either the PE or FE exams be waived based on experience or education?}

Thirty-three boards provide for certain applicants to waive the FE exam. A long history of engineering experience was one criterion that allowed applicants this option. The length of this experience varied from 6 years in California to 25 in Iowa. Several states also specified a length of time an applicant needed to be in "responsible charge" of engineering work. Sometimes an extended history of experience had to be combined with a formal engineering education. For example, Nevada law states that applicants must possess an accredited engineering degree plus 15 or more years of experience. Twelve states allow applicants with an ABET-accredited PhD to waive the FE exam.

Two states mentioned waivers for the PE examination. New Hampshire allows a waiver for the PE exam if an applicant possesses 25 years of experience, 10 of which the applicant must have held a position of responsible charge. The rules and regulations of California state that the board can waive the exam at its discretion. Figures 13 and 14 show how states deal with this issue. 


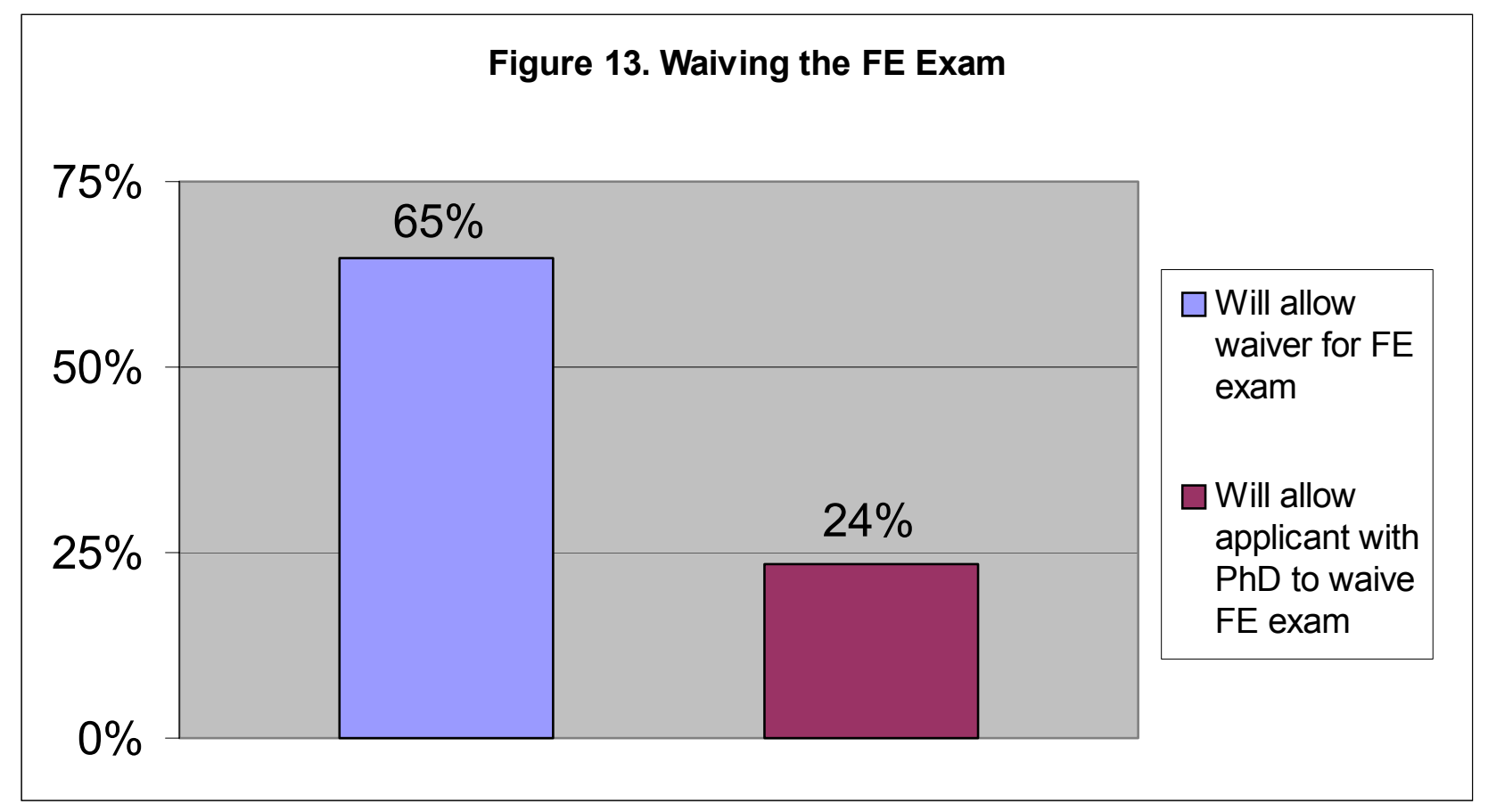

Figure 14. FE Waivers
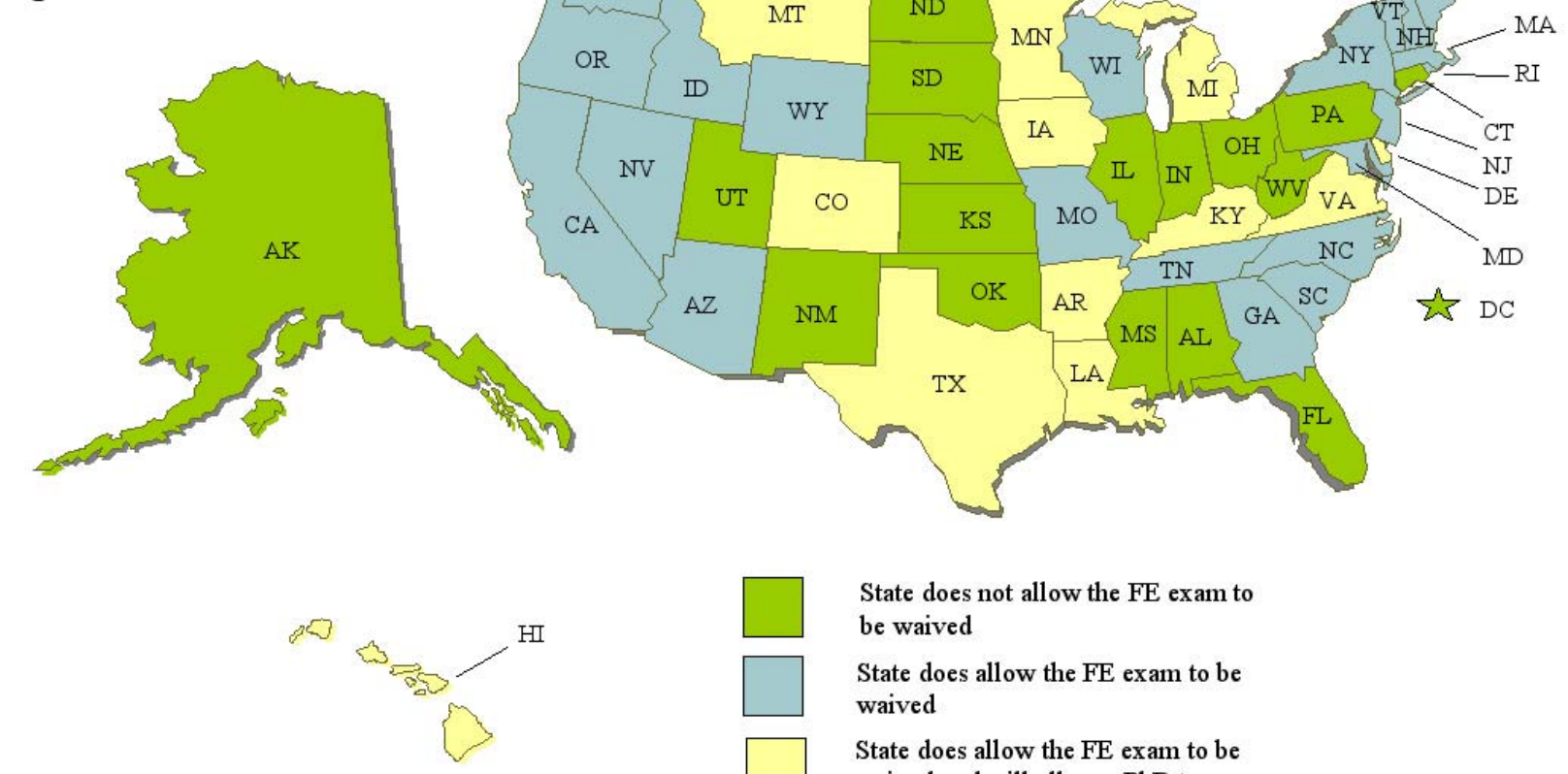

State does not allow the FE exam to be waived

State does allow the FE exam to be waived

State does allow the FE exam to be waived and will allow a $\mathrm{PhD}$ to waive the $\mathrm{FE}$ exam 


\section{Summary and Recommendations for Applicants}

Obviously, licensure is important to engineers. Engineers must be licensed to prepare, sign, and seal engineering plans for public and private clients. Licensure can be legally required for consultants, principals, and employees who hold responsibility for charge of work. Licensure has also recently taken on increased importance in industry - product safety and environmental issues are often under a microscope, and having a license helps to establish credibility with the public and the courts. Although some engineers do not perform work that requires a PE license, obtaining a license also demonstrates a firm commitment to professionalism and allows for upward mobility.

When an applicant has gained enough experience to apply to sit for the PE exam, they must write up a summary of their experience and present it to the state board. The applicants' supervisor or previous supervisors must also detail this experience in writing to the state board. For this reason, it is helpful to keep track of current and previous engineering assignments. Applicants should try not to "burn bridges." Alienated bosses and supervisors are not good references and will not provide helpful, positive feedback.

Applicants should remember that "experience" is not always the same thing as "acceptable engineering experience." Work should relate to engineering, require "a knowledge of engineering fundamentals," and progress in complexity over time as responsibility level rises. State boards are looking for PE applicants that have gained enough credible experience to acquire sound judgment. Although the board makes these decisions, it should be noted that applicants have the right to appeal any issues directly to the board for their consideration.

Students in the IAC program should take the FE exam as soon as possible. College seniors and other first-time test takers have the highest pass rates for the FE exam. The material is academic, and some of it will date back to freshman basic engineering classes. The longer an FE applicant waits to take the exam, the less likely they are to remember this type of information.

Many IAC Directors and Assistant Directors could be eligible for the PE exam. Ninety percent of the surveyed boards would allow teachers to fulfill experience requirements for the PE exam solely based on teaching experience. Twenty-four percent of the boards will also allow applicants with a $\mathrm{PhD}$ to waive the FE exam. It should also be emphasized that academic professionals write both the FE and PE exams. Professors and other academic professionals should have sufficient skills to pass these exams.

Twelve state boards will accept IAC experience as time towards licensure. The other thirteen boards that accept experience prior to graduation do not currently grant credit for IAC experience. If the IAC program desires to obtain credit from these other boards, it will need to tailor its program to more closely resemble a cooperative engineering program. In discussing this type of credit, states specifically mention these programs. The main requirements for acceptance of IAC experience under the co-op classification are that experience must be (1) under PE supervision, (2) recorded on transcripts, and (3) full-time.

There is currently a general trend away from offering credit for experience prior to graduation. As noted in the discussion of question five, some states have stopped offering this type of credit. 
Both experience prior to graduation and postgraduate credit are controversial subjects in regard to PE licensure.

The licensure process is in a state of reevaluation. The NCEES has a panel reviewing Model Law requirements. During this reevaluation period, it may be possible for IAC Directors to positively influence the decision on experience through interaction and correspondence with NCEES officials. The American Society of Civil Engineers (ASCE) has forwarded a proposal calling for a master's degree or equivalent for professional licensure. This proposal would raise the educational requirements for PEs. The National Society of Professional Engineers (NSPE) is also involved in the current licensure debate and has proposed several changes to Model Law requirements. All of these topics can be found on the NSPE web site at www.nspe.org.

\section{Notes}

1. National Council of Examiners for Engineers and Land Surveyors. (2001-2003). History. Retrieved December 11, 2002 from The National Council of Examiners for Engineers and Land Surveyors website: http://www.ncees.org/introduction/about_ncees/history.php.

2. National Council of Examiners for Engineers and Land Surveyors. (2001). Model Law, Pg. 2., Section 2: lines 12-22. Retrieved September 20, 2002, from The National Council of Examiners for Engineers and Land Surveyors website: http://www.ncees.org/introduction/about_ncees/model_law.pdf.

3. Accreditation Board for Engineering and Technology. (2002). About ABET. Retrieved December 12, 2002 from The Accreditation Board for Engineering and Technology website: http://www.abet.org/about.html.

4. National Council of Examiners for Engineers and Land Surveyors. (2001-2003). Fundamentals Exam. Retrieved December 11, 2002 from The National Council of Examiners for Engineers and Land Surveyors Web site: http://www.ncees.org/exams/fundamentals/.

5. National Council of Examiners for Engineers and Land Surveyors. (2001). Model Law, Pg. 3., Section 2: lines 31-35. Retrieved September 20, 2002, from The National Council of Examiners for Engineers and Land Surveyors website: http://www.ncees.org/introduction/about_ncees/model_law.pdf.

6. National Council of Examiners for Engineers and Land Surveyors. (2001). Model Law, Pg. 11, Section 12: lines 31-34. Retrieved September 20, 2002, from The National Council of Examiners for Engineers and Land Surveyors website: http://www.ncees.org/introduction/about_ncees/model_law.pdf.

7. National Council of Examiners for Engineers and Land Surveyors. (2001). Model Law. Retrieved September 20, 2002, from The National Council of Examiners for Engineers and Land Surveyors website: http://www.ncees.org/introduction/about_ncees/model_law.pdf.

8. National Council of Examiners for Engineers and Land Surveyors. (2001). Model Law, Pg. 8, Section 8: lines 1-10. Retrieved September 20, 2002, from The National Council of Examiners for Engineers and Land Surveyors website: http://www.ncees.org/introduction/about_ncees/model_law.pdf. 
9. National Council of Examiners for Engineers and Land Surveyors. (2001). Model Law, Pg. 8, Section 8: lines 35-37. Retrieved September 20, 2002, from The National Council of Examiners for Engineers and Land Surveyors website: http://www.ncees.org/introduction/about_ncees/model_law.pdf.

10. Mississippi State Board of Registration for Professional Engineers and Land Surveyors. (not dated). Professional Engineer License Requirements. Retrieved December 13, 2002, from The Mississippi State Board of Registration for Professional Engineers and Land Surveyors website: http://www.pepls.state.ms.us/web3.htm. 


\section{Appendix A. Foreign Degrees and Licensure}

In the United States, engineers are required to obtain a license before they offer public services or sign and seal plans for public use. Individual states and territories are responsible for the licensure of engineers. Persons wishing to become licensed must apply to the licensing board of the state or territory in which they plan to practice.

Engineers who have obtained their degree outside of the United States need to contact the appropriate licensing boards to determine the educational and experience requirements for licensure. These boards can be accessed through the National Council of Examiners for Engineers and Land Surveyors (NCEES) website. It is recommended to phone or e-mail these boards and speak with someone who specializes in evaluating educational requirements.

In addition to satisfying experience requirements for licensure, students with international degrees might be asked to contact Engineering Credential Evaluation International (ECEI). This is a service that evaluates international degrees and determines if they meet the Accreditation Board for Engineering and Technology (ABET) criteria. The basic evaluation costs $\$ 375$ and typically takes 4-6 weeks.

To pursue professional licensure in the United States, many engineering students with international degrees must prove that their educational requirements meet or exceed certain criteria prescribed by ABET. ABET is an organization that provides accreditation services for educational programs in the United States and its territories and has developed a set of minimum criteria for evaluating these programs.

Not all international degrees need to be evaluated. ABET has worked with several nations to identify equivalent programs and establish partnerships with other licensure organizations abroad.

ABET has partnered with several international accrediting agencies to form the Washington Accord. Signed in 1989, the Washington Accord is a multinational agreement with the accreditation bodies of eight countries. It allows students from all of these countries and the United States who possess degrees accredited by one of the signatory accrediting bodies to count their engineering education in any of the other countries.

ABET also conducts evaluations on educational programs outside of the United States. While these evaluations follow procedures similar to those in the United States, no accreditation can take place, and ABET acts as a consultant to the program. These evaluations can result in a program gaining status as a substantial equivalency program. This means that the program is comparable to a program accredited in the United States, and it implies that a graduate is prepared for practice at an entry level. 


\section{Appendix B. Summary of Licensing Board Survey Data}

\begin{tabular}{|c|c|c|c|c|c|c|c|c|}
\hline $\begin{array}{l}\text { State } \\
\text { Board }\end{array}$ & $\begin{array}{l}\text { Q1: General } \\
\text { requirement } \\
\text { to sit for PE } \\
\text { exam }\end{array}$ & $\begin{array}{c}\text { Q2: } \\
\text { Master's } \\
\text { credit }\end{array}$ & $\begin{array}{c}\text { Q3: } \\
\text { PhD } \\
\text { credit }\end{array}$ & $\begin{array}{c}\text { Q4: } \\
\text { Teaching } \\
\text { equivalent } \\
\text { to } \\
\text { experience? }\end{array}$ & $\begin{array}{c}\text { Q5: Co-op/ } \\
\text { Internships } \\
?\end{array}$ & $\begin{array}{c}\text { If accepted, what } \\
\text { are } \\
\text { requirements? }\end{array}$ & $\begin{array}{l}\text { Accept } \\
\text { IAC? }\end{array}$ & $\begin{array}{c}\text { Q6: Waivers for FE } \\
\text { and PE? }\end{array}$ \\
\hline $\mathrm{AL}$ & \begin{tabular}{|l} 
Accredited \\
degree +4 \\
YOE + pass \\
FE
\end{tabular} & \multicolumn{2}{|c|}{$\begin{array}{c}1 \text { yr max for } \\
\text { postgraduate } \\
\text { degrees }\end{array}$} & $\begin{array}{l}\text { Yes, if in } \\
\text { approved } \\
\text { program }\end{array}$ & $\begin{array}{l}\text { Yes, up to } 6 \\
\text { months }\end{array}$ & $\begin{array}{l}\text { Must show up on } \\
\text { transcripts and be } \\
\text { under PE }\end{array}$ & No & No \\
\hline AK & \begin{tabular}{|l} 
Accredited \\
degree +4 \\
YOE + pass \\
FE
\end{tabular} & $1 \mathrm{yr}$ & $\begin{array}{l}\text { No } \\
\text { credit }\end{array}$ & Yes & $\begin{array}{l}\text { Nothing prior } \\
\text { to graduation }\end{array}$ & $\mathrm{N} / \mathrm{A}$ & No & No \\
\hline $\mathbf{A Z}$ & $\begin{array}{l}\text { Accredited } \\
\text { degree }+4 \\
\text { YOE + pass } \\
\text { FE }\end{array}$ & $1 \mathrm{yr}$ & $\begin{array}{l}\text { No } \\
\text { credit }\end{array}$ & $\begin{array}{l}\text { Yes, but can } \\
\text { be used only } \\
\text { for a } \\
\text { maximum of } \\
1 \text { yr exp. }\end{array}$ & $\begin{array}{l}\text { Yes, up to } 6 \\
\text { months }\end{array}$ & $\begin{array}{l}\text { Case-by-case } \\
\text { basis }\end{array}$ & Yes & $\begin{array}{l}\text { Yes, waive FE if you } \\
\text { have } 12 \text { YOE after } \\
\text { gaining an ABET } \\
\text { degree }\end{array}$ \\
\hline AR & $\begin{array}{l}\text { Accredited } \\
\text { degree }+4 \\
\text { YOE + pass } \\
\text { FE } \\
\end{array}$ & $1 \mathrm{yr}$ & $1 \mathrm{yr}$ & Yes & $\begin{array}{l}\text { Nothing prior } \\
\text { to graduation }\end{array}$ & $\mathrm{N} / \mathrm{A}$ & No & $\begin{array}{l}\text { Yes, Ph.D. teaching } \\
\text { at junior or higher } \\
\text { level can waive FE } \\
\text { exam }\end{array}$ \\
\hline CA & \begin{tabular}{|l} 
Accredited \\
degree +2 \\
YOE + pass \\
FE
\end{tabular} & $1 / 2 \mathrm{yr}$ & $1 / 2 \mathrm{yr}$ & $\begin{array}{l}\text { Yes, up to } 1 \\
\text { yr credit }\end{array}$ & No & $\mathrm{N} / \mathrm{A}$ & No & $\begin{array}{l}\text { Yes, waive FE if } \\
\text { person has six years } \\
\text { exp. and accredited } \\
\text { degree. Board can } \\
\text { waive PE exam at } \\
\text { their discretion } \\
\end{array}$ \\
\hline CO & \begin{tabular}{|l} 
Accredited \\
degree +4 \\
YOE + pass \\
FE
\end{tabular} & \multicolumn{2}{|c|}{$\begin{array}{l}1 \text { yr max for } \\
\text { postgraduate } \\
\text { degrees }\end{array}$} & Yes & $\begin{array}{l}\text { Yes, up to } \\
\text { six months }\end{array}$ & $\begin{array}{l}\text { Must be prior to } \\
\text { college education, } \\
\text { cannot overlap } \\
\text { school }\end{array}$ & Yes & $\begin{array}{l}\text { Yes, waive FE if } \\
\text { person has either (1) } \\
15 \text { years of exp. (2) } \\
\text { Ph.D. from an } \\
\text { approved program } \\
\end{array}$ \\
\hline CT & \begin{tabular}{|l} 
Accredited \\
degree +4 \\
YOE + pass \\
FE
\end{tabular} & $1 \mathrm{yr}$ & $1 \mathrm{yr}$ & \begin{tabular}{|l} 
Not always, \\
must be \\
concurrent \\
with research \\
or consulting \\
\end{tabular} & $\begin{array}{l}\text { Nothing prior } \\
\text { to graduation }\end{array}$ & $\mathrm{N} / \mathrm{A}$ & No & $\begin{array}{l}\text { Yes, waive FE if } \\
\text { person has } 20+\text { YOE } \\
\text { plus a formal } \\
\text { education }\end{array}$ \\
\hline $\mathrm{DE}$ & $\begin{array}{l}\text { Accredited } \\
\text { degree }+4 \\
\text { YOE + pass } \\
\text { FE } \\
\end{array}$ & $1 \mathrm{yr}$ & $1 \mathrm{yr}$ & Yes & Yes & $\begin{array}{l}\text { Co-op experience } \\
\text { after the latter part } \\
\text { of the junior year } \\
\text { can count }\end{array}$ & No & $\begin{array}{l}\text { Yes, waive FE with } \\
\text { (1) Ph.D. or (2) } 20 \\
\text { YOE and accredited } \\
\text { degree }\end{array}$ \\
\hline DC & $\begin{array}{l}\text { Accredited } \\
\text { degree }+4 \\
\text { YOE + pass } \\
\text { FE } \\
\end{array}$ & \multicolumn{2}{|c|}{$\begin{array}{c}1 \text { yr max for } \\
\text { postgraduate } \\
\text { degrees }\end{array}$} & $\begin{array}{l}\text { Handled on a } \\
\text { case-by-case } \\
\text { basis }\end{array}$ & $\begin{array}{l}\text { Nothing prior } \\
\text { to graduation }\end{array}$ & $\mathrm{N} / \mathrm{A}$ & No & No \\
\hline FL & $\begin{array}{l}\text { Accredited } \\
\text { degree }+4 \\
\text { YOE + pass } \\
\text { FE }\end{array}$ & $1 \mathrm{yr}$ & $1 \mathrm{yr}$ & Yes & $\begin{array}{l}\text { Yes, exp. } \\
\text { can count up } \\
\text { to } 12 \text { months } \\
\text { at either } 1 / 2 \\
\text { or } 1 / 4 \text { time } \\
\end{array}$ & $\begin{array}{l}\text { Judged on a case- } \\
\text { by-case basis }\end{array}$ & Yes & No \\
\hline GA & \begin{tabular}{|l} 
Accredited \\
degree +4 \\
YOE + pass \\
FE
\end{tabular} & $1 \mathrm{yr}$ & $\begin{array}{l}\text { No } \\
\text { credit }\end{array}$ & $\begin{array}{l}\text { Yes, but } \\
\text { based on } \\
\text { individual } \\
\text { experience }\end{array}$ & $\begin{array}{l}\text { Yes, up to } \\
\text { six months }\end{array}$ & $\begin{array}{l}\text { Show up on } \\
\text { transcripts }\end{array}$ & No & $\begin{array}{l}\text { Yes, waive FE if you } \\
\text { have an accredited } \\
\text { degree and } 16 \text { YOE, } \\
8 \text { of which is } \\
\text { responsible charge }\end{array}$ \\
\hline
\end{tabular}




\begin{tabular}{|c|c|c|c|c|c|c|c|c|}
\hline State & $\begin{array}{l}\text { Q1: General } \\
\text { requirement } \\
\text { to sit for PE } \\
\text { exam }\end{array}$ & $\begin{array}{c}\text { Q2: } \\
\text { Master's } \\
\text { credit }\end{array}$ & $\begin{array}{l}\text { Q3: } \\
\text { PhD } \\
\text { credit }\end{array}$ & $\begin{array}{c}\text { Q4: } \\
\text { Teaching } \\
\text { equivalent } \\
\text { to } \\
\text { experience? }\end{array}$ & $\begin{array}{c}\text { Q5: Co-op/ } \\
\text { Internships } \\
?\end{array}$ & $\begin{array}{c}\text { If accepted, what } \\
\text { are } \\
\text { requirements? }\end{array}$ & $\begin{array}{l}\text { Accept } \\
\text { IAC? }\end{array}$ & $\begin{array}{c}\text { Q6: Waivers for FE } \\
\text { and PE? }\end{array}$ \\
\hline $\mathrm{HI}$ & $\begin{array}{l}\text { Accredited } \\
\text { degree + } 4 \\
\text { YOE }\end{array}$ & \multicolumn{2}{|c|}{$\begin{array}{c}1 \text { yr max for } \\
\text { postgraduate } \\
\text { degrees }\end{array}$} & Yes & No & $\mathrm{N} / \mathrm{A}$ & No & $\begin{array}{l}\text { Yes, } \mathrm{FE} \text { is not } \\
\text { required to take the } \\
\mathrm{PE}\end{array}$ \\
\hline IA & $\begin{array}{l}\text { Accredited } \\
\text { degree }+4 \\
\text { YOE + pass } \\
\text { FE }\end{array}$ & $1 \mathrm{yr}$ & $1 \mathrm{yr}$ & \begin{tabular}{|l} 
Yes, must be \\
under PE
\end{tabular} & Yes & $\begin{array}{l}\text { Must be full-time, } \\
\text { show up on } \\
\text { transcripts and be } \\
\text { under PE }\end{array}$ & No & $\begin{array}{l}\text { Yes, waive FE if you } \\
\text { have either (1) a PhD } \\
\text { from an approved } \\
\text { program (2) if you } \\
\text { have } 25 \text { years of exp. }\end{array}$ \\
\hline ID & \begin{tabular}{|l|} 
Accredited \\
degree +4 \\
YOE + pass \\
FE
\end{tabular} & $1 \mathrm{yr}$ & $\begin{array}{l}\text { None, } \\
\text { but } \\
\text { being } \\
\text { evaluat } \\
\text { ed }\end{array}$ & \begin{tabular}{|l|} 
Yes, but it is \\
possible that \\
additional \\
years could \\
be required \\
based on \\
type of \\
teaching \\
performed
\end{tabular} & No & $\mathrm{N} / \mathrm{A}$ & No & $\begin{array}{l}\text { Yes, waive FE based } \\
\text { on exceptional } \\
\text { stature, must have } \\
\text { references to } \\
\text { substantiate } \\
\text { extraordinary } \\
\text { activities (see pg. } 55 \\
\text { in Idaho Regulation } \\
\text { book for details) } \\
\end{array}$ \\
\hline IL & $\begin{array}{l}\text { Accredited } \\
\text { degree }+4 \\
\text { YOE + pass } \\
\text { FE }\end{array}$ & \multicolumn{2}{|c|}{$\begin{array}{c}1 \text { yr max for } \\
\text { postgraduate } \\
\text { degrees }\end{array}$} & $\begin{array}{l}\text { Yes, as long } \\
\text { as working } \\
\text { under PE }\end{array}$ & Yes & $\begin{array}{l}\text { (1) Up to } 1 \text { year } \\
\text { for c-op if it shows } \\
\text { up on transcripts } \\
\text { (2) experience } \\
\text { prior to graduation } \\
\text { if it is full-time and } \\
\text { takes eight or } \\
\text { more years to } \\
\text { graduate }\end{array}$ & No & No \\
\hline IN & $\begin{array}{l}\text { Accredited } \\
\text { degree + } 4 \\
\text { YOE + pass } \\
\text { FE }\end{array}$ & $1 \mathrm{yr}$ & $1 \mathrm{yr}$ & Yes & No & N/A & No & No \\
\hline KS & \begin{tabular}{|l} 
Accredited \\
degree +4 \\
YOE + pass \\
FE
\end{tabular} & $1 \mathrm{yr}$ & $\begin{array}{l}\text { No } \\
\text { credit }\end{array}$ & \begin{tabular}{|l|} 
Yes, handled \\
on a case- \\
by-case \\
basis
\end{tabular} & $\begin{array}{l}\text { No credit as } \\
\text { of Nov. } 1, \\
2002, \text { did } \\
\text { count } 1 / 2 \\
\text { time }\end{array}$ & N/A & No & No \\
\hline $\mathrm{KY}$ & $\begin{array}{l}\text { Accredited } \\
\text { degree }+4 \\
\text { YOE + pass } \\
\text { FE }\end{array}$ & $1 \mathrm{yr}$ & $\begin{array}{l}\text { No } \\
\text { credit }\end{array}$ & Yes & $\begin{array}{l}\text { Yes, up to } \\
\text { six months }\end{array}$ & $\begin{array}{l}\text { Based on } \\
\text { individual exp. }\end{array}$ & Yes & $\begin{array}{l}\text { Yes, waive FE if PhD } \\
\text { with } 4 \text { yrs of teaching } \\
\text { exp. }\end{array}$ \\
\hline LA & $\begin{array}{l}\text { Accredited } \\
\text { degree }+4 \\
\text { YOE + pass } \\
\text { FE }\end{array}$ & $1 \mathrm{yr}$ & \begin{tabular}{|l|}
$1 \mathrm{yr}, 2$ \\
$\mathrm{yrs}$ if no \\
master' \\
$\mathrm{s}$
\end{tabular} & Yes & Up to $1 \mathrm{yr}$ & $\begin{array}{l}\text { Must be from } \\
\text { approved co-op } \\
\text { program }\end{array}$ & No & $\begin{array}{l}\text { Yes, waive FE if } \\
\text { person has a Ph.D. } \\
\text { and a undergrad } \\
\text { from an ABET } \\
\text { accredited institution }\end{array}$ \\
\hline MA & $\begin{array}{l}\text { Accredited } \\
\text { degree + } 4 \\
\text { YOE }\end{array}$ & \begin{tabular}{|c|}
$1 \mathrm{yr}$ \\
maximu \\
$\mathrm{m}$ for \\
postgrad \\
uate \\
degrees
\end{tabular} & $\begin{array}{l}\text { Yes, but } \\
\text { experie } \\
\text { nce is } \\
\text { evaluat } \\
\text { ed on a } \\
\text { case- } \\
\text { by-case } \\
\text { basis }\end{array}$ & \begin{tabular}{|l|} 
No, this \\
experience is \\
considered \\
part of the \\
educational \\
process
\end{tabular} & N/A & No & \begin{tabular}{|l} 
Yes, a \\
person \\
with 20 \\
or more \\
YOE \\
and a \\
accredit \\
ed \\
degree \\
can
\end{tabular} & \\
\hline
\end{tabular}




\begin{tabular}{|c|c|c|c|c|c|c|c|c|}
\hline $\begin{array}{l}\text { State } \\
\text { Board }\end{array}$ & $\begin{array}{l}\text { Q1: General } \\
\text { requirement } \\
\text { to sit for PE } \\
\text { exam }\end{array}$ & $\begin{array}{c}\text { Q2: } \\
\text { Master's } \\
\text { credit }\end{array}$ & $\begin{array}{l}\text { Q3: } \\
\text { PhD } \\
\text { credit }\end{array}$ & $\begin{array}{c}\text { Q4: } \\
\text { Teaching } \\
\text { equivalent } \\
\text { to } \\
\text { experience? }\end{array}$ & $\begin{array}{l}\text { Q5: Co-op/ } \\
\text { Internships } \\
?\end{array}$ & $\begin{array}{c}\text { If accepted, what } \\
\text { are } \\
\text { requirements? }\end{array}$ & $\begin{array}{l}\text { Accept } \\
\text { IAC? }\end{array}$ & $\begin{array}{c}\text { Q6: Waivers for FE } \\
\text { and PE? }\end{array}$ \\
\hline & & & & & & & $\begin{array}{l}\text { take a } \\
\text { oral PE } \\
\text { exam }\end{array}$ & \\
\hline MD & $\begin{array}{l}\text { Accredited } \\
\text { degree + } 4 \\
\text { YOE + pass } \\
\text { FE }\end{array}$ & $\begin{array}{c}1 \mathrm{yr} \\
\text { maximu } \\
\mathrm{m} \text { for } \\
\text { postgrad } \\
\text { uate } \\
\text { degrees }\end{array}$ & Yes & $\begin{array}{l}\text { Nothing prior } \\
\text { to graduation }\end{array}$ & N/A & No & \begin{tabular}{|l|} 
Yes, \\
waive \\
FE if \\
you \\
have \\
twelve \\
years of \\
exp. \\
with five \\
yrs as \\
respons \\
ible \\
charge \\
\end{tabular} & \\
\hline ME & $\begin{array}{l}\text { Accredited } \\
\text { degree + } 4 \\
\text { YOE + pass } \\
\text { FE }\end{array}$ & $1 \mathrm{yr}$ & $1 \mathrm{yr}$ & Yes & $\begin{array}{l}\text { Nothing prior } \\
\text { to graduation }\end{array}$ & N/A & No & $\begin{array}{l}\text { Yes, until Dec. } 2004, \\
\text { if a person has } 15 \text { or } \\
\text { more yrs of exp. of } \\
\text { which at least } 10 \text { is } \\
\text { responsible charge, } \\
\text { the FE can be } \\
\text { waived }\end{array}$ \\
\hline MI & $\begin{array}{l}\text { Accredited } \\
\text { degree + } 4 \\
\text { YOE + pass } \\
\text { FE }\end{array}$ & $1 \mathrm{yr}$ & $1 \mathrm{yr}$ & Yes & $\begin{array}{l}\text { Nothing prior } \\
\text { to graduation }\end{array}$ & N/A & No & $\begin{array}{l}\text { Yes, waive FE if you } \\
\text { have a Ph.D. from an } \\
\text { accredited program }\end{array}$ \\
\hline MN & $\begin{array}{l}\text { Accredited } \\
\text { degree + } 4 \\
\text { YOE + pass } \\
\text { FE }\end{array}$ & $1 \mathrm{yr}$ & None & Yes & $\begin{array}{l}\text { Yes, up to } 2 \\
\text { year prior to } \\
\text { graduation } \\
\text { and after } 2 \text { nd } \\
\text { year, the } \\
\text { experience is } \\
\text { a } 50 \% \text { level }\end{array}$ & $\begin{array}{l}\text { Must show up on } \\
\text { transcripts, be full- } \\
\text { time, and under } \\
\text { PE }\end{array}$ & No & $\begin{array}{l}\text { Yes, waive Fe for (1) } \\
\text { persons over } 40 \text { with } \\
\text { twenty yrs of exp., } \\
\text { ten of which is } \\
\text { responsible charge } \\
\text { (2) Ph.D. from an } \\
\text { accredited program }\end{array}$ \\
\hline MO & $\begin{array}{l}\text { Accredited } \\
\text { degree + } 4 \\
\text { YOE + pass } \\
\text { FE }\end{array}$ & $\begin{array}{c}1 \mathrm{yr} \\
\text { maximu } \\
\mathrm{m} \text { for } \\
\text { postgrad } \\
\text { uate } \\
\text { degrees }\end{array}$ & Yes & $\begin{array}{l}\text { Nothing prior } \\
\text { to graduation }\end{array}$ & N/A & No & \begin{tabular}{|l|} 
Yes, \\
waive \\
FE if \\
you \\
have 20 \\
or more \\
YOE, \\
add in \\
educati \\
on \\
experie \\
nce if \\
applicab \\
le
\end{tabular} & \\
\hline MS & $\begin{array}{l}\text { Accredited } \\
\text { degree + } 4 \\
\text { YOE + pass } \\
\text { FE }\end{array}$ & $1 \mathrm{yr}$ & $2 \mathrm{yr}$ & $\begin{array}{l}\text { Yes, as long } \\
\text { as at the } \\
\text { associate } \\
\text { professor } \\
\text { level or }\end{array}$ & $\begin{array}{l}\text { Yes, up to } 6 \\
\text { months exp. }\end{array}$ & \begin{tabular}{|l|} 
Must come \\
through verifiable \\
co-op program \\
(transcripts, under \\
PE, full-time) \\
\end{tabular} & No & No \\
\hline
\end{tabular}




\begin{tabular}{|c|c|c|c|c|c|c|c|c|}
\hline $\begin{array}{l}\text { State } \\
\text { Board }\end{array}$ & $\begin{array}{l}\text { Q1: General } \\
\text { requirement } \\
\text { to sit for PE } \\
\text { exam }\end{array}$ & $\begin{array}{c}\text { Q2: } \\
\text { Master's } \\
\text { credit }\end{array}$ & $\begin{array}{l}\text { Q3: } \\
\text { PhD } \\
\text { credit }\end{array}$ & $\begin{array}{c}\text { Q4: } \\
\text { Teaching } \\
\text { equivalent } \\
\text { to } \\
\text { experience? }\end{array}$ & $\begin{array}{l}\text { Q5: Co-op/ } \\
\text { Internships } \\
?\end{array}$ & $\begin{array}{c}\text { If accepted, what } \\
\text { are } \\
\text { requirements? }\end{array}$ & $\begin{array}{l}\text { Accept } \\
\text { IAC? }\end{array}$ & $\begin{array}{c}\text { Q6: Waivers for FE } \\
\text { and PE? }\end{array}$ \\
\hline & & & & higher & & & & \\
\hline MT & $\begin{array}{l}\text { Accredited } \\
\text { degree + } 4 \\
\text { YOE + pass } \\
\text { FE }\end{array}$ & $1 \mathrm{yr}$ & $1 \mathrm{yr}$ & Yes & $\begin{array}{l}\text { Nothing prior } \\
\text { to graduation }\end{array}$ & N/A & No & $\begin{array}{l}\text { Yes, waive FE if (1) } \\
\text { you have a Ph.D. } \\
\text { from an accredited } \\
\text { program or (1) you } \\
\text { have a four yr ABET } \\
\text { accredited degree } \\
\text { and } 20 \text { or more YOE, } \\
\text { ten of which was } \\
\text { responsible charge }\end{array}$ \\
\hline NC & $\begin{array}{l}\text { Accredited } \\
\text { degree + } 4 \\
\text { YOE + pass } \\
\text { FE }\end{array}$ & $1 \mathrm{yr}$ & $1 \mathrm{yr}$ & $\begin{array}{l}\text { Yes, but only } \\
1 \mathrm{yr}\end{array}$ & Yes & $\begin{array}{l}\text { Must be part of } \\
\text { program and } \\
\text { show up on } \\
\text { transcripts }\end{array}$ & No & $\begin{array}{l}\text { Yes, waive FE if } \\
\text { person has } 20 \text { yrs of } \\
\text { exp. }\end{array}$ \\
\hline ND & $\begin{array}{l}\text { Accredited } \\
\text { degree + } 4 \\
\text { YOE + pass } \\
\text { FE }\end{array}$ & $1 \mathrm{yr}$ & $1 \mathrm{yr}$ & $\begin{array}{l}\text { Yes, can } \\
\text { count for up } \\
\text { to } 2 \text { yrs, still } \\
\text { need } 2 \text { yrs of } \\
\text { practical } \\
\text { experience }\end{array}$ & $\begin{array}{l}\text { Nothing prior } \\
\text { to graduation }\end{array}$ & N/A & No & No \\
\hline NE & $\begin{array}{l}\text { Accredited } \\
\text { degree + } 4 \\
\text { YOE + pass } \\
\text { FE }\end{array}$ & $1 \mathrm{yr}$ & $1 \mathrm{yr}$ & $\begin{array}{l}\text { Yes, } \\
\text { advanced } \\
\text { level classes } \\
\text { in a four year } \\
\text { program }\end{array}$ & $\begin{array}{l}\text { Yes, up to } \\
\text { six months }\end{array}$ & $\begin{array}{l}\text { Must be part of } \\
\text { curriculum and } \\
\text { show up on } \\
\text { transcripts }\end{array}$ & No & No \\
\hline NH & $\begin{array}{l}\text { Accredited } \\
\text { degree + } 4 \\
\text { YOE + pass } \\
\text { FE }\end{array}$ & \multicolumn{2}{|c|}{$\begin{array}{c}1 \text { yr maximum for } \\
\text { postgraduate } \\
\text { degrees }\end{array}$} & Yes & $\begin{array}{l}\text { Exp. counts } \\
\text { as long as it } \\
\text { is under PE }\end{array}$ & PE supervision & Yes & $\begin{array}{l}\text { Yes, (1) person with } \\
\text { accredited degree } \\
\text { and } 10 \text { YOE under } \\
\text { PE can waive FE (2) } \\
\text { person with } 25 \text { YOE } \\
\text { of which ten has } \\
\text { been responsible } \\
\text { charge can waive the } \\
\text { PE }\end{array}$ \\
\hline NJ & $\begin{array}{l}\text { Accredited } \\
\text { degree + } 4 \\
\text { YOE + pass } \\
\text { FE }\end{array}$ & \multicolumn{2}{|c|}{$\begin{array}{c}1 \text { yr maximum for } \\
\text { postgraduate } \\
\text { degrees }\end{array}$} & No & No & $\mathrm{N} / \mathrm{A}$ & No & $\begin{array}{l}\text { Yes, waive FE if you } \\
\text { have } 15 \text { YOE }\end{array}$ \\
\hline NM & $\begin{array}{l}\text { Accredited } \\
\text { degree + } 4 \\
\text { YOE + pass } \\
\text { FE }\end{array}$ & \multicolumn{2}{|c|}{$\begin{array}{c}1 \mathrm{yr} \text { max for } \\
\text { postgraduate } \\
\text { degrees }\end{array}$} & Yes & $\begin{array}{l}\text { Nothing prior } \\
\text { to graduation }\end{array}$ & N/A & No & No \\
\hline NV & $\begin{array}{l}\text { Accredited } \\
\text { degree + } 4 \\
\text { YOE + pass } \\
\text { FE }\end{array}$ & \multicolumn{2}{|c|}{$\begin{array}{l}\text { No credit for } \\
\text { postgraduate } \\
\text { degrees }\end{array}$} & Yes & $\begin{array}{l}\text { Nothing prior } \\
\text { to graduation }\end{array}$ & $\mathrm{N} / \mathrm{A}$ & No & $\begin{array}{l}\text { Yes, waive FE if you } \\
\text { have an accredited } \\
\text { degree plus } 15 \text { or } \\
\text { more YOE }\end{array}$ \\
\hline NY & $\begin{array}{l}\text { Accredited } \\
\text { degree + } 4 \\
\text { YOE + pass } \\
\text { FE }\end{array}$ & \multicolumn{2}{|c|}{$\begin{array}{c}1 \text { yr max for } \\
\text { postgraduate } \\
\text { degrees }\end{array}$} & $\begin{array}{l}\text { Yes, need to } \\
\text { be working } \\
\text { on upper } \\
\text { level design } \\
\text { courses, }\end{array}$ & Yes & $\begin{array}{l}\text { Case-to-case } \\
\text { based on } \\
\text { experience }\end{array}$ & Yes & $\begin{array}{l}\text { Yes, can waive FE if } \\
\text { have } 15 \text { or more } \\
\text { YOE and are of good } \\
\text { standing in the engr. } \\
\text { Community }\end{array}$ \\
\hline
\end{tabular}




\begin{tabular}{|c|c|c|c|c|c|c|c|c|}
\hline $\begin{array}{l}\text { State } \\
\text { Board }\end{array}$ & $\begin{array}{l}\text { Q1: General } \\
\text { requirement } \\
\text { to sit for PE } \\
\text { exam }\end{array}$ & $\begin{array}{c}\text { Q2: } \\
\text { Master's } \\
\text { credit }\end{array}$ & $\begin{array}{l}\text { Q3: } \\
\text { PhD } \\
\text { credit }\end{array}$ & $\begin{array}{c}\text { Q4: } \\
\text { Teaching } \\
\text { equivalent } \\
\text { to } \\
\text { experience? }\end{array}$ & $\begin{array}{l}\text { Q5: Co-op/ } \\
\text { Internships } \\
?\end{array}$ & $\begin{array}{c}\text { If accepted, what } \\
\text { are } \\
\text { requirements? }\end{array}$ & $\begin{array}{l}\text { Accept } \\
\text { IAC? }\end{array}$ & $\begin{array}{c}\text { Q6: Waivers for FE } \\
\text { and PE? }\end{array}$ \\
\hline & & & & $\begin{array}{l}\text { research or } \\
\text { consulting }\end{array}$ & & & & \\
\hline $\mathrm{OH}$ & $\begin{array}{l}\text { Accredited } \\
\text { degree + } 4 \\
\text { YOE + pass } \\
\text { FE }\end{array}$ & $1 \mathrm{yr}$ & $1 \mathrm{yr}$ & Yes & $\begin{array}{l}\text { Up to } 2 \text { years } \\
\text { prior to BS } \\
\text { degree, must } \\
\text { be gained } \\
\text { after } \\
\text { sophomore } \\
\text { year }\end{array}$ & $\begin{array}{l}\text { Same regulations } \\
\text { as experience } \\
\text { gained after } \\
\text { graduation, Ohio } \\
\text { law does not } \\
\text { require applicants } \\
\text { to work under a } \\
\text { PE }\end{array}$ & Yes & No \\
\hline OK & $\begin{array}{l}\text { Accredited } \\
\text { degree + } 4 \\
\text { YOE + pass } \\
\text { FE }\end{array}$ & $\begin{array}{l}1 \text { yr, if it } \\
\text { follows } \\
\text { ABET } \\
\text { undergra } \\
\text { duate } \\
\text { degree }\end{array}$ & $1 \mathrm{yr}$ & Yes & $\begin{array}{l}\text { Will give up } \\
\text { to } 6 \text { months } \\
\text { credit }\end{array}$ & $\begin{array}{l}\text { Must show up on } \\
\text { transcripts }\end{array}$ & No & No \\
\hline OR & $\begin{array}{l}\text { Accredited } \\
\text { degree + } 4 \\
\text { YOE + pass } \\
\text { FE }\end{array}$ & $1 \mathrm{yr}$ & $\begin{array}{l}\text { No } \\
\text { credit }\end{array}$ & Yes & No & $\mathrm{N} / \mathrm{A}$ & No & No \\
\hline PA & $\begin{array}{l}\text { Accredited } \\
\text { degree + } 4 \\
\text { YOE + pass } \\
\text { FE }\end{array}$ & \multicolumn{2}{|c|}{$\begin{array}{l}\text { No credit for } \\
\text { postgraduate } \\
\text { degrees }\end{array}$} & $\begin{array}{l}\text { Yes, if under } \\
\text { PE in } \\
\text { responsible } \\
\text { charge }\end{array}$ & $\begin{array}{l}\text { Nothing prior } \\
\text { to graduation }\end{array}$ & $\mathrm{N} / \mathrm{A}$ & No & No \\
\hline $\mathbf{R} \mathbf{I}$ & $\begin{array}{l}\text { Accredited } \\
\text { degree + } 4 \\
\text { YOE + pass } \\
\text { FE }\end{array}$ & $1 \mathrm{yr}$ & $\begin{array}{l}\text { No } \\
\text { credit }\end{array}$ & Yes & $\begin{array}{l}\text { Nothing prior } \\
\text { to graduation }\end{array}$ & N/A & No & $\begin{array}{l}\text { Yes, waive FE if you } \\
\text { possess } 12 \text { or more } \\
\text { YOE and a ABET } \\
\text { accredited degree }\end{array}$ \\
\hline SC & $\begin{array}{l}\text { Accredited } \\
\text { degree + } 4 \\
\text { YOE + pass } \\
\text { FE }\end{array}$ & $1 \mathrm{yr}$ & $1 \mathrm{yr}$ & $\begin{array}{l}\text { Yes, if at } \\
\text { assistant } \\
\text { professor } \\
\text { position or } \\
\text { higher }\end{array}$ & \begin{tabular}{|l|} 
Nothing prior \\
to graduation
\end{tabular} & $\mathrm{N} / \mathrm{A}$ & No & $\begin{array}{l}\text { Yes, } 15 \text { YOE plus } \\
\text { accredited degree }\end{array}$ \\
\hline SD & $\begin{array}{l}\text { Accredited } \\
\text { degree + } 4 \\
\text { YOE + pass } \\
\text { FE }\end{array}$ & \multicolumn{2}{|c|}{$\begin{array}{l}1 \mathrm{yr} \text { max for } \\
\text { postgraduate } \\
\text { degrees }\end{array}$} & $\begin{array}{l}\text { Yes, as long } \\
\text { as under PE }\end{array}$ & \begin{tabular}{|l|} 
Credit $1 / 2$ of \\
actual \\
experience \\
prior to \\
graduation \\
up to 1 year \\
\end{tabular} & $\begin{array}{l}\text { Case-by-case } \\
\text { basis, must be } 18 \\
\text { or older when } \\
\text { obtaining } \\
\text { experience }\end{array}$ & Yes & No \\
\hline TN & $\begin{array}{l}\text { Accredited } \\
\text { degree + } 4 \\
\text { YOE + pass } \\
\text { FE }\end{array}$ & $1 \mathrm{yr}$ & $\begin{array}{l}\text { No } \\
\text { credit }\end{array}$ & Yes & $\begin{array}{l}\text { Has not been } \\
\text { used for past } \\
\text { three years }\end{array}$ & N/A & No & $\begin{array}{l}\text { Yes, waive FE is } \\
\text { person has } 12 \text { YOE }\end{array}$ \\
\hline TX & $\begin{array}{l}\text { Accredited } \\
\text { degree + } 4 \\
\text { YOE + pass } \\
\text { FE }\end{array}$ & $1 \mathrm{yr}$ & $1 \mathrm{yr}$ & $\begin{array}{l}\text { Yes, if began } \\
\text { prior to } \\
\text { September } \\
1,2001\end{array}$ & \begin{tabular}{|l|} 
Yes, time will \\
be \\
proportioned \\
to reflect a \\
40 -hour work \\
week if \\
experience \\
was part- \\
time
\end{tabular} & $\begin{array}{l}\text { Case-by-case } \\
\text { basis based on } \\
\text { actual work and } \\
\text { references, must } \\
\text { have either } \\
\text { passed junior or } \\
\text { senior level } \\
\text { engineering } \\
\text { classes or have } \\
\text { been received }\end{array}$ & Yes & $\begin{array}{l}\text { Yes, waive FE is (1) } \\
\text { have ABET Ph.D. } \\
\text { with four yrs of } \\
\text { teaching experience } \\
\text { (2) ABET degree } \\
\text { plus } 12 \text { yrs of exp. }\end{array}$ \\
\hline
\end{tabular}




\begin{tabular}{|c|c|c|c|c|c|c|c|c|}
\hline $\begin{array}{l}\text { State } \\
\text { Board }\end{array}$ & $\begin{array}{l}\text { Q1: General } \\
\text { requirement } \\
\text { to sit for PE } \\
\text { exam }\end{array}$ & $\begin{array}{c}\text { Q2: } \\
\text { Master's } \\
\text { credit }\end{array}$ & $\begin{array}{l}\text { Q3: } \\
\text { PhD } \\
\text { credit }\end{array}$ & $\begin{array}{c}\text { Q4: } \\
\text { Teaching } \\
\text { equivalent } \\
\text { to } \\
\text { experience? }\end{array}$ & $\begin{array}{c}\text { Q5: Co-op/ } \\
\text { Internships } \\
?\end{array}$ & $\begin{array}{c}\text { If accepted, what } \\
\text { are } \\
\text { requirements? }\end{array}$ & $\begin{array}{l}\text { Accept } \\
\text { IAC? }\end{array}$ & $\begin{array}{c}\text { Q6: Waivers for FE } \\
\text { and PE? }\end{array}$ \\
\hline & & & & & & $\begin{array}{l}\text { sufficient } \\
\text { education and } \\
\text { training under an } \\
\text { engineer }\end{array}$ & & \\
\hline UT & $\begin{array}{l}\text { Accredited } \\
\text { degree + } 4 \\
\text { YOE + pass } \\
\text { FE }\end{array}$ & $1 \mathrm{yr}$ & $1 \mathrm{yr}$ & $\begin{array}{l}\text { Yes, max of } \\
3 \text { yrs }\end{array}$ & $\begin{array}{l}\text { Up to } 1 \mathrm{yr} \\
\text { prior to } \\
\text { graduation }\end{array}$ & $\begin{array}{l}\text { Case-by-case } \\
\text { basis based on } \\
\text { actual work and } \\
\text { references }\end{array}$ & Yes & No \\
\hline VA & $\begin{array}{l}\text { Accredited } \\
\text { degree + } 4 \\
\text { YOE + pass } \\
\text { FE }\end{array}$ & \begin{tabular}{|c|} 
The \\
board \\
may \\
credit at \\
their \\
discretio \\
$\mathrm{n}$, but \\
there are \\
no set \\
time \\
designati \\
ons
\end{tabular} & Yes & $\begin{array}{l}\text { Up to } 1 \mathrm{yr} \text { if } \\
\text { through an } \\
\text { approved co- } \\
\text { op program, } \\
\text { up to } 6 \\
\text { months for } \\
\text { all other } \\
\text { board } \\
\text { approved } \\
\text { experience } \\
\text { prior to } \\
\text { graduation }\end{array}$ & \begin{tabular}{|l|} 
Co-op \\
experience \\
must show \\
up on \\
transcripts, \\
be under a \\
PE and be \\
full-time work
\end{tabular} & Yes & $\begin{array}{l}\text { Yes, } \\
\text { persons } \\
\text { with a } \\
\text { Ph.D. } \\
\text { can } \\
\text { waive } \\
\text { FE and } \\
\text { so can } \\
\text { people } \\
\text { with } 20 \\
\text { YOE } \\
\text { and a 4- } \\
\text { yr } \\
\text { accredit } \\
\text { ed } \\
\text { degree }\end{array}$ & \\
\hline VT & $\begin{array}{l}\text { Accredited } \\
\text { degree + } 4 \\
\text { YOE + pass } \\
\text { FE }\end{array}$ & $1 \mathrm{yr}$ & $\begin{array}{l}\text { No } \\
\text { credit }\end{array}$ & $\begin{array}{l}\text { Not always, } \\
\text { granted on a } \\
\text { case-to-case } \\
\text { basis }\end{array}$ & $\begin{array}{l}\text { Up to } 12 \\
\text { months for } \\
\text { co-op } \\
\text { experience } \\
\end{array}$ & $\begin{array}{l}\text { Must be through } \\
\text { formal co-op } \\
\text { program }\end{array}$ & No & $\begin{array}{l}\text { Yes, waive FE if a } \\
\text { person has } 16 \text { yrs of } \\
\text { exp. }\end{array}$ \\
\hline WA & $\begin{array}{l}\text { Accredited } \\
\text { degree + } 4 \\
\text { YOE + pass } \\
\text { FE }\end{array}$ & $\begin{array}{r}1 \mathrm{yr} \mathrm{m} \\
\text { postgra } \\
\text { degr }\end{array}$ & $\begin{array}{l}\text { lax for } \\
\text { aduate } \\
\text { rees }\end{array}$ & $\begin{array}{l}\text { Yes, can } \\
\text { count a } \\
\text { maximum of } \\
2 \text { years. } \\
\text { Research } \\
\text { exp. can } \\
\text { count if work } \\
\text { is under a } \\
\text { PE and work } \\
\text { is published } \\
\end{array}$ & Yes & $\begin{array}{l}\text { Work gained on a } \\
\text { part-time basis will } \\
\text { be evaluated and } \\
\text { considered }\end{array}$ & Yes & $\begin{array}{l}\text { Yes, person can } \\
\text { waive FE if they have } \\
12 \text { YOE and have not } \\
\text { failed the test in the } \\
\text { last } 10 \text { yrs, teaching } \\
\text { is not limited to } 2 \text { yrs } \\
\text { for this purpose }\end{array}$ \\
\hline WI & $\begin{array}{l}\text { Accredited } \\
\text { degree + } 4 \\
\text { YOE + pass } \\
\text { FE }\end{array}$ & $1 \mathrm{yr}$ & $1 \mathrm{yr}$ & Yes & Yes & $\begin{array}{l}\text { Must show up on } \\
\text { transcripts, be full- } \\
\text { time co-op }\end{array}$ & No & $\begin{array}{l}\text { Yes, waive FE if } 8 \text { or } \\
\text { more YOE + ABET } \\
\text { accredited degree }\end{array}$ \\
\hline $\mathbf{W V}$ & $\begin{array}{l}\text { Accredited } \\
\text { degree + } 4 \\
\text { YOE + pass } \\
\text { FE }\end{array}$ & $1 \mathrm{yr}$ & $1 \mathrm{yr}$ & $\begin{array}{l}\text { Yes, as long } \\
\text { as under PE }\end{array}$ & $\begin{array}{l}\text { Nothing prior } \\
\text { to graduation }\end{array}$ & $\mathrm{N} / \mathrm{A}$ & No & No \\
\hline WY & $\begin{array}{l}\text { Accredited } \\
\text { degree }+4 \\
\text { YOE + pass } \\
\text { FE }\end{array}$ & \multicolumn{2}{|c|}{$\begin{array}{l}1 \text { yr max for } \\
\text { postgraduate } \\
\text { degrees }\end{array}$} & $\begin{array}{l}\text { Yes, but on a } \\
\text { case-by-case } \\
\text { basis }\end{array}$ & $\begin{array}{l}\text { Nothing prior } \\
\text { to graduation }\end{array}$ & $\mathrm{N} / \mathrm{A}$ & No & $\begin{array}{l}\text { Yes, waive FE if } 20 \\
\text { or more YOE + ABET } \\
\text { accredited degree }\end{array}$ \\
\hline
\end{tabular}


Appendix C. Letter to State Board Regarding Licensure Credit, IAC Brochure 
September 2, 2002

$<$ Contact $>$

$<$ State Board of Licensure $>$

$<$ Street Address $>$

$<$ City, State, Zip $>$

\section{Dear $<$ State Board $>$,}

I am writing to you on behalf of the engineering Students and Alumni of the U.S. Department of Energy's (DOE's) Industrial Assessment Center (IAC) Program, regarding experience credit towards Professional Engineering Licensure.

It is my understanding that experience credit for licensure varies greatly from state to state. Based on the NCEES Model Law, experience is defined as "...four (4) years or more of progressive experience on engineering projects of a grade and character which indicates to the board that the applicant may be competent to practice engineering..." Many states grant experience credit up to one year for completion of an engineering graduate degree or for experience obtained in an established cooperative education program. It is the desire of the students and alumni of the IAC Program that State Engineering Boards across the country consider IAC participation as qualified experience towards licensure.

The IAC Program was established by DOE in 1976 to help U.S. manufacturers address energy, waste, and productivity issues and reduce operating costs. DOE-funded centers located at 26 top ABET-accredited engineering colleges across the U.S. (see attached list) work with local manufacturers to identify opportunities to reduce energy consumption, minimize waste, and improve productivity. The centers are led by qualified engineering faculty (many are registered P.E.'s) and staffed by top-performing undergraduate and graduate-level engineering students. Each IAC team conducts assessments for a minimum of 25 industrial clients per year. Assessments include an on-site visit, detailed engineering report, and follow-up presentation of results. To date over 10,000 U.S. manufacturers have saved more than $\$ 700$ million through efficiency and productivity improvements identified by IAC students and faculty.

Over 2,000 engineering students have participated in the IAC program since its inception, and 50 percent of our alumni are either registered Professional Engineers or Engineers-In-Training. IAC students typically work on a part-time basis during the school year, and many work full time during breaks in their academic schedules. The university-based centers are funded by DOE on the basis of a competitive solicitation and are often integrated into engineering curricula through related courses and/or coursework offered by participating engineering faculty. Certificates of Participation are issued by the DOE and the host 
engineering college to departing students who have successfully met the IAC performance criteria, which includes at least two semesters of participation, and development of skills in teamwork, leadership, written and verbal communications, technical problem solving and conceptual design. For more details on the IAC program, please see the enclosed brochure.

Through their participation in this program, the wide range of engineering experience gained by IAC students equals or exceeds that gained by students in cooperative or intern programs. It is my hope that your Board of Engineers will be open to considering IAC experience as credit towards licensure experience for future applicants. You will receive a follow-up call from either myself, or my assistant, Kurt Stafford, within the next few weeks to answer any questions that your board might have regarding the IAC program. In the meantime, you may contact me at 865-574-8688 or martinma@ornl.gov, or Kurt Stafford at 865-386-7911 or kstaffo1@utk.edu.

Sincerely,

Michaela A. Martin, PE

IAC Alumna, Texas A\&M - Class of 1993

Attachments: List of Participating Schools

IAC Student Brochure

Cc: IAC Directors

File - RC 
Arizona State University

Bradley University

Colorado State University

Georgia Institute of Technology

Iowa State University

Lehigh University

Loyola Marymount University

Mississippi State University

North Carolina State University

Oklahoma State University

Oregon State University

Syracuse University

San Diego State University

San Francisco State University

Texas A \& M University

West Virginia University

University of Dayton

University of Florida

University of Illinois - Chicago

University of Louisiana at Lafayette

University of Massachusetts

University of Miami

University of Michigan

University of Texas - Arlington

University of Utah

University of Wisconsin - Milwaukee 


\section{About the IAC Program}

The U.S. Department of Energy's Industrial Assessment Center (IAC) program is a product of the energy crisis our country faced in the 1970's. It employs engineering students at ABET accredited institutions to assess manufacturing plants and identify measures that will save energy, minimize waste, enhance productivity, and reduce operating costs. Students work for the IAC on a part-time basis, under direct supervision of engineering faculty and staff. The program. launched in 1976 with only four schools, currently consists of 26 colleges and universities across the country. In the mid 1990's, the program's scope expanded to include evaluations of waste minimization, pollution prevention, and productivity enhancement. There have been over 10,000 IAC assessments performed by over 2.000 students from the fields of mechanical. electrical, industrial, civil, and chemical engineering.

\section{The Assessment Process}

The first step in the IAC assessment process requires a team of students to perform a preliminary engineering analysis by examining the plant's utility bills for energy and water, studying how waste is handled, reviewing the plant layout, and collecting production and operating data.After the information is analyzed, the team formulates a strategic plan for the site visit.

Once on site, the team tours the plant and identifies efficiency recommendations by testing and inspecting the plant's equipment and procedures.Additional data are collected through interviews or discussions with the plant's staff.The initial findings are then presented to the plant's management.
Next, a comprehensive report is developed detailing an engineering analysis of recommendations, implementation cost estimates, and savings estimates. Approximately six months after the final report is delivered, the IAC team performs a follow-up survey to find out which recommendations have been implemented.

\section{Technical Scope of IAC Assessments}

Students who participate in the IAC program encounter a variety of manufacturing situations. Since the program's inception over 25 years ago, IAC teams have visited a wide range of manufacturing plants within Standard Industrial Classification (SIC) codes 20-39 including suppliers of plastic and fabricated metal products, electronic components, motor vehicle equipment, dairy products, and paperboard containers. Due to the diversity of possible assessment recommendations. students are often required to address issues outside their immediate areas of expertise.

The following is a breakdown of major assessment recommendation categories along with some topics IAC students deal with on a regular basis:

- Energy - combustion systems, thermal systems, electrical power, motors, building envelope, HVAC, and lighting

- Waste Minimization and Pollution Prevention-waste stream contamination, equipment, post-generation treatment, water use, solid and liquid recycling. waste disposal, and efficient use of raw materials

- Productivity-manufacturing enhancements. purchasing, inventory, labor optimization, space utilization, and reduction of downtime

\section{Benefits of the IAC Experience}

By performing supervised IAC assessments, graduate and undergraduate engineering students are afforded a unique opportunity to gain valuable real-world knowledge. Unlike standard engineering internships and co-op programs, the IAC program exposes students to a wider range of technical experiences and challenges that help them develop practical skills and better prepare them for their career. These experiences allow IAC alumni to hit the ground running when entering the professional marketplace.

Each Industrial Assessment Center is managed by a senior member of the host school's engineering faculty. There are currently 20 registered professional engineers and four certified energy managers serving as Directors programwide. Students from various disciplines such as mechanical, civil, electrical, chemical, and industrial engineering are encouraged to participate.

\section{Roles and Responsibilities}

Throughout their tenure in the IAC program, students are engaged in a progressive engineering experience. Before they can participate in an assessment, new students must undergo training on IAC procedures, products and safety during their first semester. They will then typically support more experienced team members by collecting data during site visits and assisting in the development of assessment reports.

Intermediate level students focus on developing the ability to identify and address technical solutions in the areas of energy, waste, and productivity. Lead Students-a title designating veterans of the program with more than one 
year's experience-work with the center's Director to develop assessment reports, coordinate assessment teams, and handle administrative duties. Other responsibilities of Lead Students include training of new students and representing their school at national IAC student meetings.

\section{IAC Certification}

The Department of Energy issues IAC Certificates of Participation to students who successfully meet performance criteria established by the IAC Directors. To earn a certificate, a candidate must be employed by the program for a minimum of two semesters or two summer sessions, participate in a minimum of six assessments, and demonstrate IAC Core Skills including client interaction, teamwork, report writing, leadership, and technical ability.

\section{IAC Alumni Feedback}

The manufacturers that implement energy, waste, and productivity saving recommendations are not the only benefactors of the IAC experience. In a recent survey conducted by Oak Ridge National Laboratory, IAC alumni were asked to reflect on the benefits of their program experience. Over 78 percent stated that participation improved their ability to communicate ideas in writing and to work in teams. Additionally, over 70 percent noted an increased ability to solve problems within the constraints of time. money and human resources, as well as improved confidence in their ability to make appropriate recommendations.

The survey also focused on alumni demographics including current employers, memberships in professional organizations and licensure status. Approximately 64 percent of IAC alumni are active in professional organizations such as

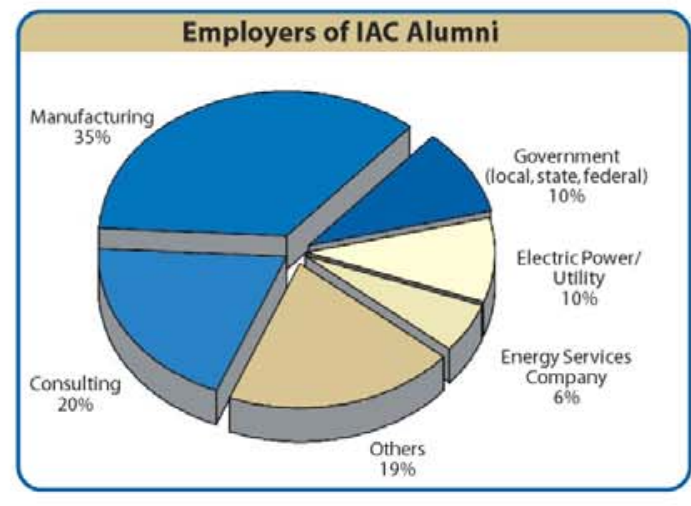

ASHRAE, AEE, ASME, SAE and ASEE. Thirty-five percent are employed in a manufacturing environment (many were actually recruited by their former IAC clients), while 20 percent are active consultants. The most impressive statistic found that over 50 percent of IAC alumni are either registered Professional Engineers (PE) or Engineers-InTraining (EIT).

\section{Additional Information}

- General Program Information-For more information on the Industrial Assessment Center program, visit www.oit.doe.gov/iac or contact Sandy Glatt at (303)-275-4857,email: sandy.glatt@ee.doe.gov

- IAC Student Recruiting Information-For more information on IAC student activities, including employer recruiting, career opportunities, and student resumes, visit www.iacforum.org or contact Michaela Martin at (865) 574-8688, email: martinma@ornl.gov
The U.S. Department of Energy's

\section{Industrial Assessment Center Student Development Program}

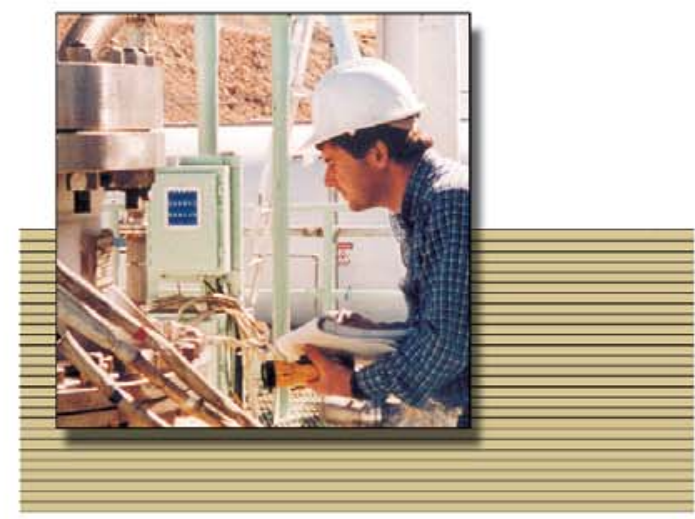

Providing today's engineering

students with the experience

to become tomorrow's

energy efficiency experts 